\title{
Observations and model calculations of trace gas scavenging in a dense Saharan dust plume during MINATROC
}

\author{
M. de Reus ${ }^{1}$, H. Fischer ${ }^{1}$, R. Sander ${ }^{1}$, V. Gros ${ }^{1,3}$, R. Kormann ${ }^{1}$, G. Salisbury ${ }^{1}$, R. Van Dingenen ${ }^{2}$, J. Williams ${ }^{1}$, M. \\ Zöllner $^{1}$, and J. Lelieveld ${ }^{1}$ \\ ${ }^{1}$ Max Planck Institute for Chemistry, PO Box 3060, 55020 Mainz, Germany \\ ${ }^{2}$ Joint Research Centre, Ispra, Italy \\ ${ }^{3}$ now at: Laboratoire des Sciences du Climat et de l'Environnement (LSCE), Gif sur Yvette, France
}

Received: 13 January 2005 - Published in Atmos. Chem. Phys. Discuss.: 11 February 2005

Revised: 2 May 2005 - Accepted: 13 June 2005 - Published: 20 July 2005

\begin{abstract}
An intensive field measurement campaign was performed in July/August 2002 at the Global Atmospheric Watch station Izaña on Tenerife to study the interaction of mineral dust aerosol and tropospheric chemistry (MINATROC). A dense Saharan dust plume, with aerosol masses exceeding $500 \mu \mathrm{g} \mathrm{m}^{-3}$, persisted for three days. During this dust event strongly reduced mixing ratios of $\mathrm{RO}_{\mathrm{x}}\left(\mathrm{HO}_{2}\right.$, $\mathrm{CH}_{3} \mathrm{O}_{2}$ and higher organic peroxy radicals), $\mathrm{H}_{2} \mathrm{O}_{2}, \mathrm{NO}_{\mathrm{x}}(\mathrm{NO}$ and $\mathrm{NO}_{2}$ ) and $\mathrm{O}_{3}$ were observed. A chemistry boxmodel, constrained by the measurements, has been used to study gas phase and heterogeneous chemistry. It appeared to be difficult to reproduce the observed $\mathrm{HCHO}$ mixing ratios with the model, possibly related to the representation of precursor gas concentrations or the absence of dry deposition. The model calculations indicate that the reduced $\mathrm{H}_{2} \mathrm{O}_{2}$ mixing ratios in the dust plume can be explained by including the heterogeneous removal reaction of $\mathrm{HO}_{2}$ with an uptake coefficient of 0.2 , or by assuming heterogeneous removal of $\mathrm{H}_{2} \mathrm{O}_{2}$ with an accommodation coefficient of $5 \times 10^{-4}$. However, these heterogeneous reactions cannot explain the low $\mathrm{RO}_{\mathrm{x}}$ mixing ratios observed during the dust event. Whereas a mean daytime net ozone production rate (NOP) of $1.06 \mathrm{ppb}_{\mathrm{v}} / \mathrm{hr}$ occurred throughout the campaign, the reduced $\mathrm{RO}_{\mathrm{x}}$ and $\mathrm{NO}_{\mathrm{x}}$ mixing ratios in the Saharan dust plume contributed to a reduced NOP of $0.14-0.33 \mathrm{ppb}_{\mathrm{v}} / \mathrm{hr}$, which likely explains the relatively low ozone mixing ratios observed during this event.
\end{abstract}

Correspondence to: M. de Reus

(reus@mpch-mainz.mpg.de)

\section{Introduction}

The interaction between atmospheric aerosols and photochemistry via heterogeneous reactions has been subject to intense investigation during the last decades. As an example, heterogeneous reactions on polar stratospheric clouds lead to the destruction of stratospheric ozone (e.g. Crutzen and Arnold, 1986). Heterogeneous reactions on cloud droplets and aerosols are also found to be important for tropospheric chemistry (e.g. Lelieveld and Crutzen, 1990). Special emphasis has been given to reactions on mineral dust aerosol (e.g. Usher et al., 2003), since these particles provide a large surface area for heterogeneous reactions in the troposphere (IPCC, 1996).

During several field campaigns a correlation between high dust loadings and low $\mathrm{O}_{3}$ and $\mathrm{HNO}_{3}$ concentrations has been observed (e.g. de Reus et al., 2000; Hanke et al., 2003; Bonasoni et al., 2004). The latter authors also showed that dustpoor airmasses originating in North Africa had significantly higher $\mathrm{O}_{3}$ concentrations than those which carried dust.

Chemical boxmodels as well as global and regional chemical-transport models have been used to calculate the reduction in trace gas mixing ratios due to heterogeneous reactions on mineral dust aerosol. Most studies focussed on ozone and nitrogen species, while only a few studies report effects of mineral dust on $\mathrm{OH}$ and $\mathrm{HO}_{2}$ mixing ratios. Zhang et al. (1994) and Zhang and Carmichael (1999), for example, used a boxmodel to simulate the loss of $\mathrm{SO}_{2}, \mathrm{NO}_{\mathrm{x}}, \mathrm{HO}_{2}$ and $\mathrm{O}_{3}$ due to heterogeneous reactions on mineral dust aerosol. Dentener et al. (1996) performed simulations with a global chemistry-transport model and calculated an $\mathrm{O}_{3}$ reduction up to $10 \%$ in and nearby dust source areas. De Reus et al. (2000) calculated a 30-40\% reduction of $\mathrm{O}_{3}$ in a Saharan dust plume near the coast of Africa, attributed to the direct removal of $\mathrm{O}_{3}$ by dust aerosol and the heterogeneous removal of $\mathrm{HNO}_{3}$.

(C) 2005 Author(s). This work is licensed under a Creative Commons License. 
Bauer et al. (2004) calculated a 5\% reduction in global tropospheric ozone and concluded that this was mainly due to the uptake of $\mathrm{HNO}_{3}$ on dust aerosol and not due to the direct uptake of $\mathrm{O}_{3}$. However, the $\mathrm{HNO}_{3}$ concentration was overestimated by the global model, which may have strongly biased the results of this study. Bian and Zender (2003) investigated the effect of reduced photolysis rates and heterogeneous chemistry on the tropospheric trace gas mixing ratios. They concluded that both processes cause a combined decrease in global mean $\mathrm{O}_{3}$ of $0.7 \%$, and $11.1 \%$ for $\mathrm{OH}, 5.2 \%$ for $\mathrm{HO}_{2}$ and $3.5 \%$ for $\mathrm{HNO}_{3}$. The effects of heterogeneous removal reactions clearly dominated over the reduced photolysis rates. Tang et al. (2004) performed a model study using a regional-scale chemistry-transport model and compared the results with aerosol chemical composition measurements in a dust plume encountered during the ACE-Asia measurement campaign. They investigated both the reduction in solar (actinic) radiation and heterogeneous reactions on the dust aerosol. Low $\mathrm{O}_{3}$ concentrations in the dust plume could only be explained by heterogeneous reactions. It was inferred that the reduction of photolysis rates largely determines changes in $\mathrm{OH}$ concentrations, whereas the large decrease in $\mathrm{HNO}_{3}$ (up to $95 \%$ ) and $\mathrm{SO}_{2}$ (up to 55\%) concentrations was due to heterogeneous reactions.

Although all aforementioned studies indicate a strong influence of mineral dust aerosols on tropospheric chemistry, the results are very different. This is mainly due to the large uncertainty in the uptake coefficients for the different trace gases on mineral dust aerosols. Moreover, for boxmodel calculations it has proven difficult to provide realistic initial conditions, and for all models the comparison with observations is a main challenge.

In this study we use an alternative approach. We employ a chemical boxmodel to analyse measurements performed within a dense Saharan dust plume at the Izaña observatory on Tenerife, Canary Islands. We use the model to calculate the steady state concentrations of $\mathrm{RO}_{\mathrm{x}}, \mathrm{H}_{2} \mathrm{O}_{2}$ and $\mathrm{HCHO}$ and compare them with observed values. For the model initialisation measured quantities are used to the extent possible. In addition to heterogeneous $\mathrm{O}_{3}$ and $\mathrm{HNO}_{3}$ uptake and the reduction of photolysis rates by mineral dust aerosol, as addressed in previous studies, we focus on the effects of $\mathrm{HO}_{2}$ and $\mathrm{H}_{2} \mathrm{O}_{2}$ uptake in this study. Furthermore, we compare the net ozone production rate in the Saharan dust plume with airmasses not containing dust.

\section{The MINATROC experiment}

The MINATROC (MINeral dust And TROpospheric Chemistry) project was designed to investigate the effects of heterogeneous reactions involving mineral aerosol on tropospheric chemistry. The project combined three types of research activities: laboratory experiments to quantify selected interactions between trace gases and mineral dust aerosol, field experiments to study the influence of mineral dust on tropospheric chemistry under realistic conditions, and global model studies to put the results of the former two into perspective. In this paper we will present observations of the second field experiment, performed in July/August 2002 at the Izaña observatory on the island of Tenerife, Spain.

Izaña observatory is part of the World Meteorological Organisation (WMO) Global Atmospheric Watch (GAW) network, and is operated by the Spanish Meteorological Institute. The station is situated on a mountain ridge on the island of Tenerife at $2360 \mathrm{~m}$ above sea level (a.s.l., $28^{\circ} 18^{\prime} \mathrm{N}$, $16^{\circ} 29^{\prime} \mathrm{W}$ ). Between 15 July and 15 August 2002 intensive aerosol and trace gas measurements were performed. The influence of mineral dust on the chemistry of the troposphere could be studied extensively during this period, since, besides several smaller dust episodes, a major dust event was probed between 28 and 31 July 2002.

\section{Instrumentation}

Additional to the set of measurements of the global watch program at Izaña, intensive measurements of aerosols and trace gases were performed during MINATROC by different institutes.

The instruments to measure atmospheric trace gases were operated by the Max Planck Institute for Chemistry, Mainz, Germany, from two laboratory containers. A sample air inlet was placed at the roof of both containers about $4 \mathrm{~m}$ above the ground. The $\mathrm{RO}_{\mathrm{x}}$ instrument and the upward looking $\mathrm{JNO}_{2}$ and $\mathrm{JO}^{1} \mathrm{D}$ filter radiometers were deployed directly on the roof of the container at about $3 \mathrm{~m}$ above ground level, while the downward looking $\mathrm{JNO}_{2}$ and $\mathrm{JO}^{1} \mathrm{D}$ filter radiometers were mounted at a height of $1.5 \mathrm{~m}$ above ground level.

Table 1 lists the trace gas instruments which are relevant for this study, together with their associated uncertainties and detection limits. Since most instruments are similar to the ones which have been used during the first MINATROC field experiment at Mt. Cimone in June 2000, a detailed description of the $\mathrm{O}_{3}, \mathrm{CO}, \mathrm{RO}_{\mathrm{x}}, \mathrm{NO}$ and $\mathrm{NO}_{\mathrm{y}}$ instruments can be found in Fischer et al. (2003). For the other instruments more details are given below.

A liquid chemistry fluorescence detector (AERO laser model AL 4021) was used to measure formaldehyde ( $\mathrm{HCHO}$ ). The instrument first strips the $\mathrm{HCHO}$ from the ambient air into a strongly diluted $\mathrm{H}_{2} \mathrm{SO}_{4}$ solution, after which it reacts with acetylacetone and ammoniumacetate to form 3,5-diacetyl-1,4-dihydrolutidine (DDL) following the Hantzsch reaction. The fluorescence signal of the excited reaction product is detected by a photomultiplier at $510 \mathrm{~nm}$. The same instrument has been employed during a previous aircraft campaign (Kormann et al., 2003).

For the determination of $\mathrm{H}_{2} \mathrm{O}_{2}$ a second liquid chemistry fluorescence detector has been used (AERO laser model AL 2001CA). After stripping $\mathrm{H}_{2} \mathrm{O}_{2}$ from the ambient air in a 
Table 1. Instrumentation used for trace gas measurements during MINATROC.

\begin{tabular}{|c|c|c|c|c|}
\hline Species & Measurement principle & Instrument & Uncertainty & Detection limit \\
\hline $\mathrm{O}_{3}$ & UV absorption & Ansyco 41M & $<5 \%$ & $1 \mathrm{ppb}_{\mathrm{V}}$ \\
\hline $\mathrm{CO}$ & Gas chromatograph & Thermo-Electron & $5 \%$ & \\
\hline NO & chemiluminescence detector (CLD) & ECOPHYSICS CLD 790SR & $3 \%$ & $8 \mathrm{ppt}_{\mathrm{V}}$ \\
\hline $\mathrm{NO}_{2}$ & CLD and photolytic converter (PLC) & ECOPHYSICS CLD 790SR and PLC 760 & $\begin{array}{l}8 \% \text { at night, } \\
20 \% \text { during the day }\end{array}$ & $24 \mathrm{ppt}_{\mathrm{V}}$ \\
\hline $\mathrm{NO}_{\mathrm{y}}$ & CLD and catalytic converter & ECOPHYSICS CLD 770AL & $5.6 \%$ & $100 \mathrm{ppt}_{\mathrm{V}}$ \\
\hline $\mathrm{HCHO}$ & Fluorescence detector (Hantzsch reaction) & Aero Laser AL4021 & $5 \%$ & $23 \mathrm{ppt}_{\mathrm{V}}$ \\
\hline $\mathrm{H}_{2} \mathrm{O}_{2}$ & $\begin{array}{l}\text { Fluorescence detector } \\
\text { (dual enzyme tecnique) }\end{array}$ & Aero Laser AL2001CA & $20 \%$ & $60 \mathrm{ppt}_{\mathrm{V}}$ \\
\hline $\mathrm{CH}_{3} \mathrm{OOH}$ & Fluorescence detector & AL2001CA & $100 \%^{1}$ & $60 \mathrm{ppt}_{\mathrm{V}}$ \\
\hline $\mathrm{RO}_{\mathrm{x}}$ & $\begin{array}{l}\text { Chemical amplifier and } \\
\text { photoluminescence detector }\end{array}$ & PERCA and Luminox LMA-3 & $30-40 \%$ & $2 \mathrm{ppt}_{\mathrm{V}}$ \\
\hline $\begin{array}{l}\text { Acetone, } \\
\text { methanol, } \\
\text { isoprene }\end{array}$ & $\begin{array}{l}\text { Proton-Transfer-Reaction Mass } \\
\text { Spectrometer (PTRMS) }\end{array}$ & & $<28 \%$ & $\begin{array}{l}55 \mathrm{ppt}_{\mathrm{V}} \\
213 \mathrm{ppt}_{\mathrm{V}} \\
46 \mathrm{ppt}_{\mathrm{V}}\end{array}$ \\
\hline Propane, butane & $\begin{array}{l}\text { Gas chromatograph-mass } \\
\text { spectrometer (GC-MS) }\end{array}$ & Agilent GC-MS 6890/5973 & $<15 \%$ & $3 \mathrm{ppt}_{\mathrm{V}}$ \\
\hline $\mathrm{JO}^{1} \mathrm{D}$ & Filter Radiometer & METCON & $20 \%^{2}-30 \%^{3}$ & $8 \times 10^{-7} s^{-1}$ \\
\hline $\mathrm{JNO}_{2}$ & Filter Radiometer & METCON & $10 \%^{2}-20 \%^{3}$ & $8 \times 10^{-7} \mathrm{~s}^{-1}$ \\
\hline
\end{tabular}

${ }^{1}$ Estimated uncertainty for the $\mathrm{CH}_{3} \mathrm{OOH}$ measurements, see text.

${ }^{2}$ For solar zenith angles $<60^{\circ}$

${ }^{3}$ For solar zenith angles between $60^{\circ}$ and $70^{\circ}$

slightly acidic solution, this instrument determines the total peroxide concentration by the liquid phase reaction of peroxides with p-hydroxyphenylacetic acid, catalysed by peroxidase. To distinguish between $\mathrm{H}_{2} \mathrm{O}_{2}$ and organic peroxides two parallel channels are used. In one channel $\mathrm{H}_{2} \mathrm{O}_{2}$ is selectively destroyed by the enzyme catalase prior to the fluorescence detection in the instrument. The difference between the signals from both channels is a measure for the $\mathrm{H}_{2} \mathrm{O}_{2}$ concentration (Lazrus et al., 1986).

No quantification of organic peroxides can be achieved without knowing the specific peroxide composition in the atmosphere. This is due to the high variability in the relative amounts of peroxides in ambient air, the large variations in Henry's law constants, and, consequently, the collection efficiencies for these compounds. However, if we assume that the most abundant organic peroxide in the atmosphere is methylhydroperoxide (MHP, $\mathrm{CH}_{3} \mathrm{OOH}$ ) and that the collection efficiency of MHP is $60 \%$, an upper limit for the MHP mixing ratio can be determined. The obtained $\mathrm{CH}_{3} \mathrm{OOH}$ mixing ratio should, however, be interpreted with considerable care.

The calibration of both AERO laser detectors was carried out both in the gas and the liquid phase. HCHO calibration gas was produced using a VICI Metronics permeation tube operated at a temperature of $80^{\circ} \mathrm{C}$, while for $\mathrm{H}_{2} \mathrm{O}_{2}$ a home-built permeation device was used, consisting of a semi- permeable polyethylene tube which was placed in a saturated $\mathrm{H}_{2} \mathrm{O}_{2}$ environment (glass bottle with a small amount of $30 \%$ $\mathrm{H}_{2} \mathrm{O}_{2}$ solution, operated at a constant temperature of $30^{\circ} \mathrm{C}$ ). Zero air (CAP60 Headline Filters air purifier) with a total flow of $6 \mathrm{~L} / \mathrm{min}$ was mixed with the calibration gas stream leading to a mixing ratio of $13.3 \mathrm{ppb}_{\mathrm{v}} \mathrm{HCHO}$ and $5.9 \mathrm{ppb}_{\mathrm{v}}$ $\mathrm{H}_{2} \mathrm{O}_{2}$. Every 4-6 h calibration gas was added to the sample air at the top of the sample mast, to determine the losses of $\mathrm{HCHO}$ and $\mathrm{H}_{2} \mathrm{O}_{2}$ in the inlet line. To test the stability of the instrument, additional liquid calibrations were performed once a day with $1 \mu \mathrm{M} \mathrm{HCHO}$ and $\mathrm{H}_{2} \mathrm{O}_{2}$ solutions. Laboratory calibrations show that $7.4 \% \pm 2.7 \%$ of the $\mathrm{H}_{2} \mathrm{O}_{2}$ is lost in the inlet line, while no reduction of the $\mathrm{HCHO}$ mixing ratio was observed due to the long inlet line.

Measurements of a range of volatile organic carbons (VOC) were performed using a proton-transfer-reaction mass spectrometer (PTRMS). Inside this instrument organic species are chemically ionised by the proton transfer with $\mathrm{H}_{3} \mathrm{O}^{+}$ions and the products are detected with a quadrupole mass spectrometer (Lindinger et al., 1998). In this study the measurements of acetone, methanol and isoprene are used. The isoprene mixing ratios measured with the PTRMS, however, should be regarded as upper limits, due to other possible contributions to this mass (Williams et al., 2001). More details about the measurement technique and calibration procedure can be found in Salisbury et al. (2003). 
For the measurement of non methane hydrocarbons (NMHC) stainless steel canister samples were taken every 3 or $6 \mathrm{~h}$ during the campaign, which were analysed in the laboratory of the Max Planck Institute in Mainz, using a gas chromatograph-mass spectrometer system (GC-MS). Due to the set-up of the GC-MS system only hydrocarbons with more than $2 \mathrm{C}$ atoms were analysed. More details about the collection of the samples, the GS-MS system and its calibration procedure can be found in Gros et al. (2003).

Aerosol measurements were performed from a mobile laboratory by the Joint Research Centre, Ispra, Italy. Dry aerosol size distributions in the size range 6-600 $\mathrm{nm}$ diameter were measured with a custom built Vienna type differential mobility analyser (DMA), using a TSI CPC model 3010 as particle counter (Thermo Systems Inc. Condensation Particle Counter). The number size distribution of coarse particles was determined with an Optical Particle Counter (OPC, GRIMM model 1.108) in 15 size classes from $300 \mathrm{~nm}$ to $10 \mu \mathrm{m}$ diameter. Note that the aerosols entering the OPC have not been dried, however, for the low relative humidities $(<60 \%)$ observed during the campaign, the observed aerosol diameter can be regarded as dry diameter. Combining the data of both instruments provides the aerosol size distribution between $6 \mathrm{~nm}$ and $10 \mu \mathrm{m}$ diameter, from which the total aerosol surface area and volume was calculated. Total PM10 (particle diameter (Dp) $<10 \mu \mathrm{m}$ ) aerosol mass was obtained on-line with a tapered element oscillating microbalance (TEOM) system, with a total uncertainty of $\pm 15 \%$.

\section{Meteorology}

The synoptic situation over the Canary Islands is usually dominated by a subtropical anticyclone, centred over the Azores (Carslaw et al., 1997). Deviations in the position of this anticyclone generally determine the origin of the airmasses observed at the Izaña observatory. During the MINATROC campaign in July/August 2002 four regions of origin could be identified based on backtrajectories calculated with the HYSPLIT model (HYbrid Single-Particle Lagrangian Integrated Trajectory, http://www.arl.noaa.gov/ready/hysplit4. html): north Atlantic, central Atlantic, tropical Africa and the Sahara region.

Several time periods with airmasses containing mineral dust, originating in the Sahara region and tropical Africa could be identified. The strongest Saharan dust plume was observed between 28 and 31 July. Aerosol index images from the TOMS satellite indicate that this dust plume originated in western Algeria and its border region with Mali and Mauritania. Backtrajectory calculations suggest that the airmasses were lifted from between 500 and $1500 \mathrm{~m}$ above ground level to the measurement altitude of about $2.5 \mathrm{~km}, 2.5$ to 3 days before arrival at the Izaña measurement station, and originate more to the southwest in Mauritania. Lidar measurements indicate that the Saharan dust plume extended to an altitude of about $7 \mathrm{~km}$ (pers. comm. G. P. Gobbi, 2003).

\section{Observations}

The mixing ratios of a selection of trace gases together with the observed temperature, relative humidity, aerosol number concentration and aerosol surface area are shown in Fig. 1. Continuous in-situ measurements were performed between 16 July and 15 August 2002. Due to instrument calibrations some short gaps occur in the dataset. A delay in the analytic gas shipment to the measurement station precluded $\mathrm{RO}_{\mathrm{x}}$ measurements between 22 July and 29 July. Moreover, due to inlet problems no reliable measurements of acetone, methanol, isoprene and NMHC could be obtained before 29 July. The dataset has been reduced to $30 \mathrm{~min}$ averaged values, except for the aerosol mass concentrations for which only hourly averages are available.

Figure 2 shows the average diurnal cycle for a selection of species observed during the campaign. A strong diurnal cycle was observed for most trace gases and the aerosol number concentration. This is mainly driven by local air circulation patterns at the measurement site, which are typical for a highelevation mountainous site. During daytime the air flows upward to the sampling site resulting from surface warming (upslope winds), while downslope winds are observed during the night, due to cooling of the mountain slopes (Zaveri et al., 1995). As a result, free tropospheric air masses were observed during the night and airmasses influenced by anthropogenic pollution from the local boundary layer during the day.

The fraction of boundary layer air which has been mixed into the free tropospheric airmasses at the measurement station has been estimated using relative humidity profiles obtained by radiosondes launched in Santa Cruz, the capital of Tenerife, situated at the south-western coast of the island (Schultz, 1995). For this method three water vapour mixing ratios are used: (1) the $\mathrm{H}_{2} \mathrm{O}$ mixing ratio measured at the Izaña station $\left(\mathrm{H}_{2} \mathrm{O}_{i z o}\right)$, (2) the $\mathrm{H}_{2} \mathrm{O}$ mixing ratio measured by the radiosonde in the free troposphere at the same altitude as the measurement station $\left(\mathrm{H}_{2} \mathrm{O}_{F T}\right)$ and (3) the $\mathrm{H}_{2} \mathrm{O}$ mixing ratio measured by the radiosonde in the marine boundary layer at $100 \mathrm{~m}$ a.s.l. $\left(\mathrm{H}_{2} \mathrm{O}_{\mathrm{MBL}}\right)$. The mixing factor can then be defined as: $\left(\mathrm{H}_{2} \mathrm{O}_{\text {izo }}-\mathrm{H}_{2} \mathrm{O}_{\mathrm{FT}}\right) /\left(\mathrm{H}_{2} \mathrm{O}_{\mathrm{MBL}}-\mathrm{H}_{2} \mathrm{O}_{\mathrm{FT}}\right)$. Since only two radiosondes were launched per day only one instantaneous daytime value for the mixing factor could be obtained per day. The daytime mixing factor ranged between -30 and $65 \%$ and had a median value of $17 \%(\mathrm{~N}=28)$ in the dust-poor airmasses. During the major dust event the measurements were less influenced by local pollution. Since the dust event lasted for three days, only three numbers for the mixing factor could be determined, namely $-30 \%, 0.8 \%$ and $17 \%$, which were all below the median mixing factor of the dust-poor airmasses. 

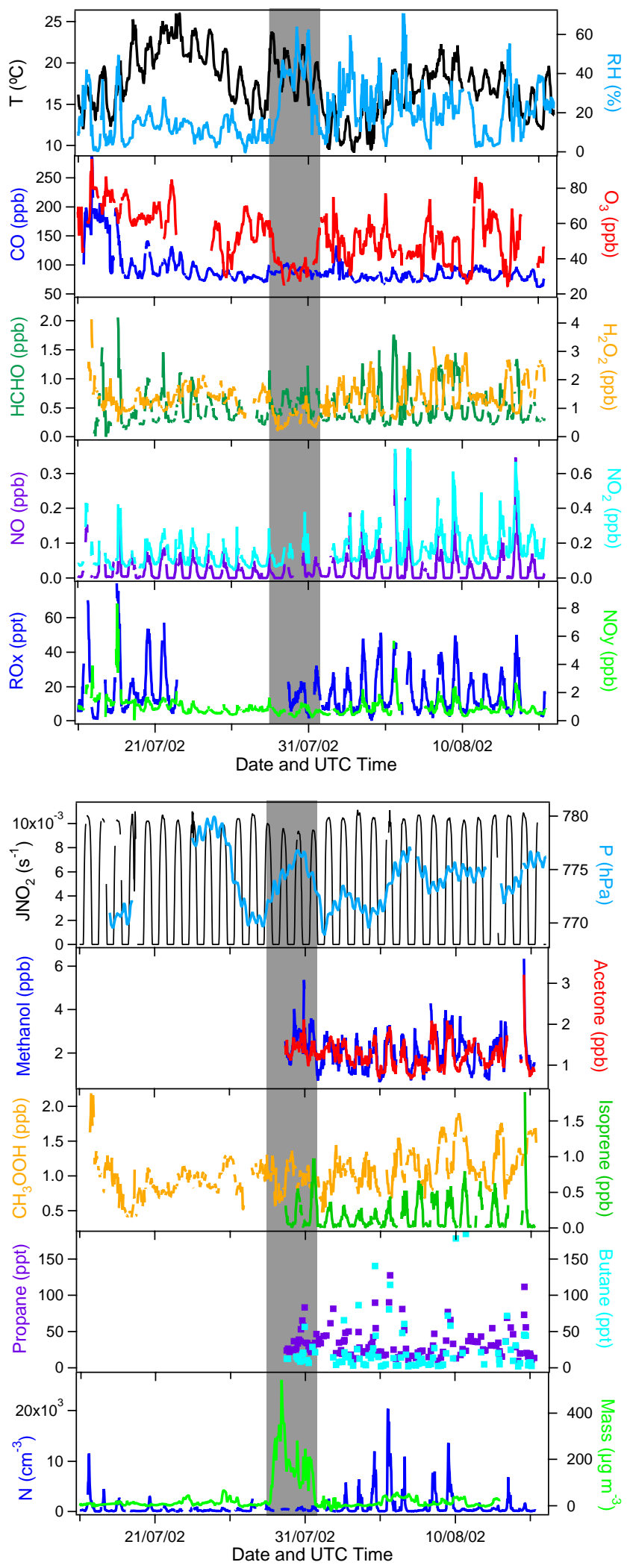

Fig. 1. Time series of the observed meteorological parameters, trace gas mixing ratios and aerosol number and mass concentrations during MINATROC. The major Saharan dust event is marked by the grey area. 

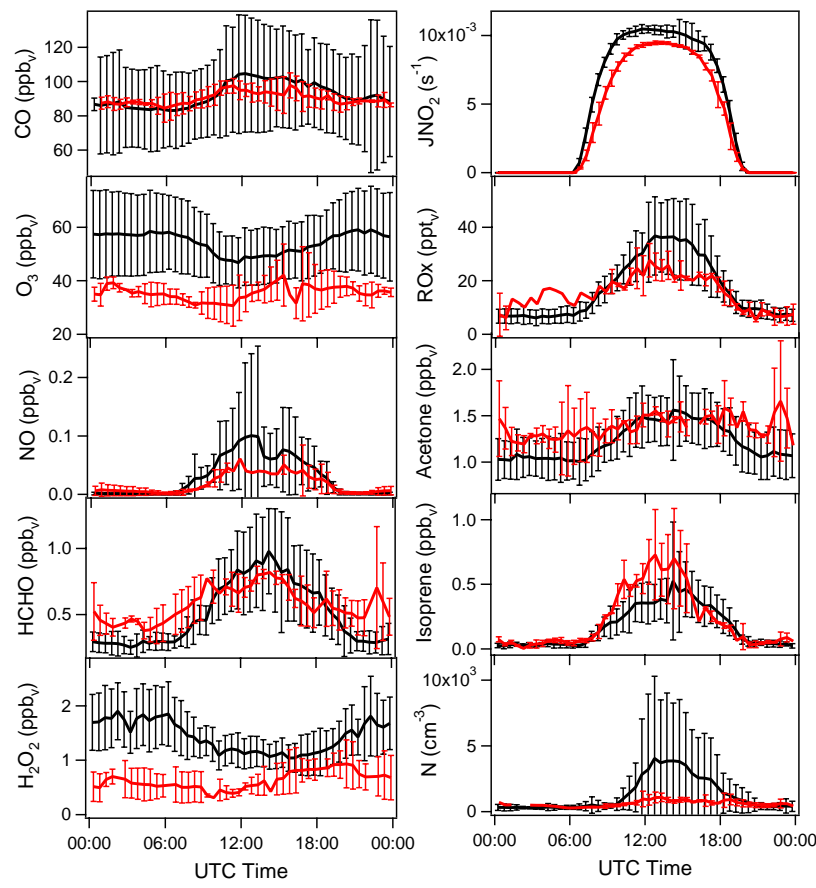

Fig. 2. Diurnal variation of a selection of trace gases and the aerosol number concentration during MINATROC. The red line represents the observations (and $1 \sigma$ standard deviation) during the major Saharan dust event, the black line the data outside the dust event.

Note that biogenic emissions from vegetation at the slopes of the mountain close to the measurement site influence the observed trace gas mixing ratios at the measurement site in a different manner than anthropogenic emissions, which are transported over a much larger distance from the marine boundary layer. Hence, the calculated mixing factor is a good indicator for the influence of antropogenic pollution from the marine boundary layer, but not for the influence of more local biogenic emissions.

For $\mathrm{CO}, \mathrm{NO}_{\mathrm{x}}$, methanol, acetone and aerosols the upslope winds resulted in an enhancement of the concentrations during the day, due to the intrusion of anthropogenic pollution from the boundary layer. On the other hand $\mathrm{O}_{3}$ and $\mathrm{H}_{2} \mathrm{O}_{2}$ mixing ratios were lower during the day, as a result of their positive vertical gradients in the lower atmosphere, mainly due to enhanced destruction of these species by dry deposition at the surface. The $\mathrm{RO}_{\mathrm{x}}$ and $\mathrm{HCHO}$ mixing ratios closely followed the solar radiation intensity. For these shorter lived species the diurnal variation is less affected by transport and much more dependent on local photochemical production, maximizing around local noon.

For a statistical analysis of the data, upslope and downslope conditions have been separated. Upslope conditions could be identified by a strong enhancement in aerosol number concentration and occurred between 07:00 and 21:00 UTC (daytime), downslope conditions correspondingly between 21:00 and 07:00 UTC (nighttime). Average
Table 2. Average values for meteorological parameters, trace gas mixing ratios and aerosol properties (aerosol number concentration $(\mathrm{N})$, surface area (A), volume (V) and mass) observed during the Saharan dust event and for the dust-poor airmasses. The dataset is subdivided in daytime (upslope) and nighttime (downslope) conditions. Note that VOC and NMHC data are only available after 28 July. For all other parameters data from the entire campaign have been used to determine the average concentrations.

\begin{tabular}{|c|c|c|c|c|}
\hline & \multicolumn{2}{|c|}{ Daytime } & \multicolumn{2}{|c|}{ Nighttime } \\
\hline & dust poor & dust event & dust poor & dust event \\
\hline Temperature $\left({ }^{\circ} \mathrm{C}\right)$ & $18.2 \pm 3.5$ & $20.0 \pm 1.6$ & $15.8 \pm 3.3$ & $17.2 \pm 1.6$ \\
\hline RH (\%) & $19 \pm 11$ & $35 \pm 13$ & $16 \pm 12$ & $37 \pm 15$ \\
\hline $\mathrm{CO}\left(\mathrm{ppb}_{\mathrm{v}}\right)$ & $96 \pm 27$ & $92 \pm 6$ & $87 \pm 29$ & $87 \pm 3$ \\
\hline $\mathrm{O}_{3}\left(\mathrm{ppb}_{\mathrm{v}}\right)$ & $52 \pm 12$ & $35 \pm 6$ & $58 \pm 15$ & $36 \pm 3$ \\
\hline $\mathrm{HCHO}\left(\mathrm{ppb}_{\mathrm{v}}\right)$ & $0.65 \pm 0.32$ & $0.64 \pm 0.14$ & $0.29 \pm 0.08$ & $0.47 \pm 0.16$ \\
\hline $\mathrm{H}_{2} \mathrm{O}_{2}\left(\mathrm{ppb}_{\mathrm{V}}\right)$ & $1.24 \pm 0.38$ & $0.64 \pm 0.28$ & $1.72 \pm 0.55$ & $0.61 \pm 0.25$ \\
\hline $\mathrm{CH}_{3} \mathrm{OOH}\left(\mathrm{ppb}_{\mathrm{v}}\right)^{1}$ & $1.0 \pm 0.26$ & $0.93 \pm 0.16$ & $1.1 \pm 0.34$ & $0.99 \pm 0.21$ \\
\hline $\mathrm{NO}_{\mathrm{X}}\left(\mathrm{ppb}_{\mathrm{V}}\right)$ & $0.26 \pm 0.20$ & $0.17 \pm 0.07$ & $0.10 \pm 0.04$ & $0.11 \pm 0.05$ \\
\hline $\mathrm{NO}_{\mathrm{y}}\left(\mathrm{ppb}_{\mathrm{v}}\right)$ & $1.14 \pm 0.75$ & $0.74 \pm 0.24$ & $0.77 \pm 0.38$ & $0.51 \pm 0.20$ \\
\hline $\mathrm{RO}_{\mathrm{x}}(\mathrm{ppt})^{2}$ & $43 \pm 16$ & $28 \pm 6$ & - & - \\
\hline Methanol $\left(\mathrm{ppb}_{\mathrm{v}}\right)$ & $2.35 \pm 0.66$ & $2.8 \pm 0.5$ & $1.40 \pm 0.43$ & $2.3 \pm 0.8$ \\
\hline Acetone $\left(\mathrm{ppb}_{\mathrm{v}}\right)$ & $1.34 \pm 0.31$ & $1.4 \pm 0.13$ & $1.05 \pm 0.23$ & $1.3 \pm 0.24$ \\
\hline Isoprene $\left(\mathrm{ppb}_{\mathrm{v}}\right)$ & $0.27 \pm 0.21$ & $0.35 \pm 0.26$ & $0.03 \pm 0.02$ & $0.05 \pm 0.02$ \\
\hline Propane $\left(\mathrm{ppt}_{\mathrm{v}}\right)$ & $41 \pm 25$ & $38 \pm 15$ & $22 \pm 11$ & $34 \pm 18$ \\
\hline Butane $\left(\mathrm{ppt}_{\mathrm{V}}\right)$ & $35 \pm 37$ & $15 \pm 6$ & $13 \pm 31$ & $24 \pm 28$ \\
\hline $\mathrm{N}\left(\mathrm{cm}^{-3}\right)$ & $1463 \pm 2451$ & $551 \pm 230$ & $261 \pm 186$ & $364 \pm 119$ \\
\hline $\mathrm{A}\left(\mu \mathrm{m}^{2} \mathrm{~cm}^{-3}\right)$ & $27 \pm 23$ & $152 \pm 86$ & $16 \pm 16$ & $155 \pm 54$ \\
\hline $\mathrm{V}\left(\mu \mathrm{m}^{3} \mathrm{~cm}^{-3}\right)$ & $3.8 \pm 4.1$ & $50 \pm 29$ & $3.4 \pm 4.7$ & $55 \pm 19$ \\
\hline Mass $\left(\mu \mathrm{g} \mathrm{m}^{-3}\right)$ & $13 \pm 14$ & $186 \pm 116$ & $12 \pm 16$ & $199 \pm 61$ \\
\hline
\end{tabular}

1 The $\mathrm{CH}_{3} \mathrm{OOH}$ given here is an upper limit for the atmospheric $\mathrm{CH}_{3} \mathrm{OOH}$ mixing ratio.

${ }^{2}$ For $\mathrm{RO}_{\mathrm{x}}$ the average daytime maximum mixing ratio is given.

daytime and nighttime values for the observed trace gas mixing ratios and aerosol number concentration, surface area, volume and mass are listed in Table 2.

Table 2 and Fig. 2 also distinguish airmasses containing dust from those which were not influenced by dust. During the measurement campaign several Saharan dust events were probed with PM10 aerosol mass concentrations exceeding $25 \mu \mathrm{g} \mathrm{m}^{-3}$. The most pronounced dust event was probed between 28 July, 16:45 UTC and 31 July, 15:15 UTC, when aerosol mass concentrations up to $500 \mu \mathrm{g} \mathrm{m}^{-3}$ were observed, and the aerosol optical thickness above the measurement station reached values of 0.95 . In air masses which were not influenced by Saharan dust, these values were below $10 \mu \mathrm{g} \mathrm{m}^{-3}$ and 0.5 , respectively. For the analyses in this paper we focus on this major dust event and treat the minor dust events as "dust-poor" airmasses. The time period of the Saharan dust event has been marked by a grey box in Fig. 1 .

Some of the observed trace gases show a distinct change during the dust event. The most pronounced is the decrease in ozone mixing ratio from about $65 \mathrm{ppb}_{\mathrm{v}}$ just before the dust event started to below $35 \mathrm{ppb}_{\mathrm{v}}$ during the 
dust event $\left(\mathrm{ppb}_{\mathrm{v}}=\mathrm{nmol} / \mathrm{mol}\right)$. At the same time relatively low $\mathrm{H}_{2} \mathrm{O}_{2}$ mixing ratios were observed. In free tropospheric air masses (nighttime), an average $\mathrm{H}_{2} \mathrm{O}_{2}$ mixing ratio of $0.61 \pm 0.25 \mathrm{ppb}_{\mathrm{v}}$ was observed during the dust period, whereas it was $1.72 \pm 0.55 \mathrm{ppb}_{\mathrm{v}}$ during the rest of the campaign. Also Fig. 2 depicts significantly lower $\mathrm{O}_{3}$ and $\mathrm{H}_{2} \mathrm{O}_{2}$ mixing ratios in airmasses containing dust compared to dustpoor air. Unfortunately no $\mathrm{RO}_{\mathrm{x}}$ measurements were available for the first half of the dust period, although during the second part of the dust period lower $\mathrm{RO}_{\mathrm{x}}$ peak values, i.e. $23 \mathrm{ppt}_{\mathrm{v}}$ at $30 \mathrm{July}$ and $32 \mathrm{ppt}_{\mathrm{v}}$ at 31 July were observed compared to the dust-poor days $\left(43 \pm 16 \mathrm{ppt}_{\mathrm{v}}\right)$. Moreover, a difference in $\mathrm{NO}_{\mathrm{x}}$ mixing ratio was found between dust and dustpoor airmasses, which could be a result of the suppressed transport of boundary layer air to the measurement station during the dust event. During upslope conditions $0.17 \mathrm{ppb}_{\mathrm{v}}$ $\mathrm{NO}_{\mathrm{x}}$ was found in the dust plume, while $0.26 \mathrm{ppb}_{\mathrm{v}} \mathrm{NO}_{\mathrm{x}}$ was observed in the dust-poor airmasses. An additional and possibly more significant effect may be the heterogeneous loss of $\mathrm{HNO}_{3}$ and $\mathrm{N}_{2} \mathrm{O}_{5}$ on the dust particles, which indirecty deplete $\mathrm{NO}_{\mathrm{x}}$. The mean relative humidity during the Saharan dust episode was $35 \%$, with peak values up to $60 \%$. This is high compared to the relative humidity observed during the rest of the campaign.

An inhibition of the acetone and methanol diurnal cycle could be observed throughout the dust event, with enhanced mixing ratios during the night, indicating a slightly altered nocturnal wind pattern. On the other hand, enhanced isoprene mixing ratios were found in the dust plume during the day, indicating a greater influence of local biogenic emissions during the dust event. Furthermore, no significant change in the $\mathrm{HCHO}$ and $\mathrm{CO}$ mixing ratio was observed.

Although a strong decrease in the $\mathrm{HNO}_{3}$ mixing ratio is expected in a mineral dust plume (e.g. Dentener et al., 1996) and observed by Hanke et al. (2003), no significant change in the $\mathrm{NO}_{\mathrm{y}}$ mixing ratio was observed. This is due to the fact that the $\mathrm{NO}_{\mathrm{y}}$ converter measures the sum of all gaseous nitrogen species and aerosol nitrate. Hence, the uptake of $\mathrm{HNO}_{3}$ on mineral dust aerosol is not expected to show up in the $\mathrm{NO}_{\mathrm{y}}$ measurements. Remarkably, the mean daytime aerosol number concentration is highest in the dust-poor airmasses, which may also be explained by a reduced mixing of boundary layer air in the dust plume. The much higher particle surface area and mass concentration observed during the dust event indicates a very different aerosol size distribution in the dust loaded airmasses, with a higher number of larger particles. The small particles are probably scavenged by the larger Saharan dust aerosols in the plume, reducing the total aerosol number concentration. The photolysis rates of $\mathrm{O}_{3}$ and $\mathrm{NO}_{2}$ are reduced in the dust plume due to the absorption and scattering of solar radiation by the dense aerosol. The average daytime $\mathrm{JNO}_{2}$ photolysis rate decreased by $17 \%$ and $\mathrm{JO}^{1} \mathrm{D}$ by $15 \%$ during the Saharan dust event compared to the rest of the campaign.
Table 3. Comparison of the median daytime and nighttime (day/night) trace gas mixing ratios during the MINATROC campaign at Izaña and at Mt. Cimone and during the OCTA campaign at Izaña in July/August 1993. For $\mathrm{RO}_{\mathrm{x}}$ only a mean noontime value is given. Only the dust-poor data from MINATROC is used for this comparison.

\begin{tabular}{lccc}
\hline & Izaña & Mt. Cimone $^{1}$ & Izaña $^{2}$ \\
\hline Field campaign & MINATROC & MINATROC & OCTA \\
Time period & July/August 2002 & June 2000 & July/August 1993 \\
$\mathrm{O}_{3}\left(\right.$ ppb $\left._{\mathrm{v}}\right)$ & $52 / 59$ & $56 / 60$ & $38 / 40$ \\
$\mathrm{CO}\left(\mathrm{ppb}_{\mathrm{v}}\right)$ & $88 / 78$ & $119 / 118$ & $92 / 89$ \\
$\mathrm{NO}_{\mathrm{x}}\left(\mathrm{ppt}_{\mathrm{v}}\right)$ & $210 / 95$ & $267 / 197$ & $76 / 47$ \\
$\mathrm{NO}_{\mathrm{y}}\left(\mathrm{ppb}_{\mathrm{v}}\right)$ & $0.95 / 0.66$ & $0.90 / 1.0$ & $0.52 / 0.39$ \\
$\mathrm{HCHO}\left(\mathrm{ppb}_{\mathrm{v}}\right)$ & $0.58 / 0.29$ & $1.4 / 1.1$ & $1.4 / 1.1$ \\
$\mathrm{H}_{2} \mathrm{O}_{2}\left(\mathrm{ppb}_{\mathrm{v}}\right)$ & $1.17 / 1.63$ & n.a. & $2.1 / 2.4$ \\
$\mathrm{RO}_{\mathrm{x}}\left(\mathrm{ppt}_{\mathrm{v}}\right)$ & 43 & 31 & 65 \\
\hline
\end{tabular}

${ }^{1}$ Fischer et al. (2003)

${ }^{2}$ Fischer et al. (1998)

Another interesting observation is the very high $\mathrm{CO}$ and $\mathrm{O}_{3}$ mixing ratios during the first two days of the measurement campaign, which could be attributed to long range transport of a biomass burning plume from large forest fires in Quebec, Canada, on 6-9 July 2002. During these two days $\mathrm{CO}$ mixing ratios as high as $290 \mathrm{ppb}_{\mathrm{v}}$ and $\mathrm{O}_{3}$ mixing ratios of $100 \mathrm{ppb}_{\mathrm{v}}$ were observed. Although very interesting, this period will not be further studied in this paper.

A comparison of the observed trace gas mixing ratios with observations made during the first MINATROC field campaign on Mt. Cimone in June 2000 (Fischer et al., 2003) is presented in Table 3. The Mt. Cimone station is situated at $2165 \mathrm{~m}$ a.s.l. on the highest mountain in the northern Italian Apennines $\left(44^{\circ} 11^{\prime} \mathrm{N}, 10^{\circ} 42^{\prime} \mathrm{E}\right)$. Due to its location in southern Europe, the sampled airmasses represent European continental background conditions. Similar $\mathrm{O}_{3}$ mixing ratios have been observed at both measurements sites, while the $\mathrm{CO}$ and $\mathrm{NO}_{\mathrm{x}}$ mixing ratios were slightly lower at Izaña, indicative of a more remote site, though influenced by continental pollution. The HCHO mixing ratios observed at Izaña were, however, much lower than those observed at Mt. Cimone. The results from the MINATROC campaign are also compared with measurements at the Izaña observatory performed in July/August 1993 during the OCTA field campaign (Fischer et al., 1998). Compared to the measurements at the same site nine years earlier, slightly higher $\mathrm{O}_{3}$ and $\mathrm{NO}_{\mathrm{x}}$ mixing ratios and much lower $\mathrm{HCHO}$ and $\mathrm{H}_{2} \mathrm{O}_{2}$ mixing ratios were observed in 2002. This appears to be consistent with an upward $\mathrm{O}_{3}$ trend observed downwind of western Africa (Lelieveld et al., 2004). The median nighttime CO mixing ratio in 2002 was $9 \mathrm{ppb}_{\mathrm{v}}$ lower than that observed in 1993, in line with the observed CO trend of $-0.92 \pm 0.15 \mathrm{ppb}_{\mathrm{v}} / \mathrm{yr}$ in the northern hemisphere lower troposphere (Novelli et al., 
2003). The observed $\mathrm{RO}_{\mathrm{x}}$ mixing ratios were similar, taking into account the large uncertainty in the $\mathrm{RO}_{\mathrm{x}}$ measurements .

\section{Boxmodel calculations}

To investigate photochemistry, net ozone production and the influence of Saharan dust aerosol on the mixing ratios of peroxy radicals, formaldehyde and hydrogen peroxide, model calculations were performed with the chemistry box model MECCA (Module Efficiently Calculating the Chemistry of the Atmosphere). The chemical reaction scheme has been adopted from von Kuhlmann et al. (2003) and includes detailed chemistry of organic species with up to four C-atoms and isoprene (Sander et al., 2004). The reaction rates have generally been adopted from the Jet Propulsion Laboratory (JPL) 2003 database (Sander et al., 2003). Heterogeneous removal reactions of $\mathrm{HO}_{2}$ and $\mathrm{H}_{2} \mathrm{O}_{2}$ on mineral dust have been added to the chemical scheme, analogous to de Reus et al. (2000). In total 67 chemical species, 110 gas phase chemical reactions, 34 photolysis reactions and 2 heterogeneous removal reactions were included (see electronic supplement).

The boxmodel has been employed by constraining the concentrations of relatively long-lived trace gases to the observed values (see next section for a detailed description), whereas the steady state concentrations of short-lived trace gases are calculated. Here, we focus on peroxy radicals, formaldehyde and hydrogen peroxide.

\subsection{Input parameters}

Since two sets of observations are available per hour, a model simulation is started every $30 \mathrm{~min}$. Each simulation has been initialised with the observed temperature, pressure, $\mathrm{O}_{3}$, $\mathrm{CO}, \mathrm{H}_{2} \mathrm{O}, \mathrm{NO}, \mathrm{H}_{2} \mathrm{O}_{2}, \mathrm{CH}_{3} \mathrm{OOH}$, acetone, methanol, isoprene, propane and butane mixing ratios, which are shown in Fig. 1. Short gaps for which data are missing have been filled through interpolation. $\mathrm{HNO}_{3}$ is initialised using the observed $\mathrm{NO}_{\mathrm{z}}$ mixing ratio $\left(\mathrm{NO}_{\mathrm{z}}=\mathrm{NO}_{\mathrm{y}}-\mathrm{NO}_{\mathrm{x}}\right)$. Since $\mathrm{NO}_{\mathrm{y}}$ also includes atmospheric aerosol nitrate, $\mathrm{HNO}_{3}$ will likely be strongly overestimated during the dust event when $\mathrm{NO}_{\mathrm{z}}$ is used as a proxy for $\mathrm{HNO}_{3}$ (see Sect. 5). Therefore, $\mathrm{HNO}_{3}$ is set to zero during the major Saharan dust event. For $\mathrm{CH}_{4}$ and $\mathrm{CO}_{2}$ background mixing ratios for the year 2002 of 1.75 and $372 \mathrm{ppm}_{\mathrm{v}}$ have been used, respectively. Since no measurements of ethane, ethene and propene were performed during MINATROC, the mixing ratios of these species were scaled to the observed propane mixing ratio using the mean daytime mixing ratios observed during a former campaign at Izaña in July/August 1993 (Fischer et al., 1998). During this campaign the mean ratios of ethane, ethene and propene to propane were $10,0.6$ and 0.2 , respectively.

$\mathrm{JO}^{1} \mathrm{D}$ and $\mathrm{JNO}_{2}$ photolysis rates were measured during the campaign and have been used as reaction rates for the photolysis reaction of $\mathrm{O}_{3}$ (to $\mathrm{O}^{1} \mathrm{D}$ ) and $\mathrm{NO}_{2}$, respectively.
Other photolysis rates have been calculated using the Tropospheric Ultraviolet-Visible (TUV, version 4.1) radiation model (Madronich and Flocke, 1998). For these calculations, the total ozone column measured with a Dobson spectrometer at the Izaña station has been used as input value, while default values for the $\mathrm{SO}_{2}, \mathrm{NO}_{2}$, cloud and aerosol optical depth were used. To account for cloud overpasses and the reduction of solar radiation due to the Saharan dust plume, the calculated photolysis rates have been scaled to the ratio of the measured to the calculated $\mathrm{JNO}_{2}$ photolysis rates.

A model simulation has been performed for every $30 \mathrm{~min}$ data point during daytime hours (solar zenith angle $<70^{\circ}$ ). The mixing ratios of the above listed trace gases, temperature, pressure and photolysis rates have been kept constant during each simulation, while the model was run for 10 days, to make sure that steady state was achieved. Since no VOC and NMHC data are available before 29 July, only the later part of the campaign has been analysed.

\subsection{Gas phase chemistry}

Before we performed model simulations for the MINATROC dataset, we first carried out some calculations to determine the time needed to reach steady state for different species. We defined the steady state time as the time the boxmodel needs to reach a mixing ratio which did not change more than $1 \%$ in the last $30 \mathrm{~min}$. The steady state time has been determined for different solar zenith angles during a randomly chosen day during the campaign. When no isoprene is included in the model calculations, steady state concentrations of $\mathrm{HCHO}$ and $\mathrm{RO}_{\mathrm{x}}$ were reached after 9 and $6 \mathrm{~h}$, respectively, at local noon and after $33 \mathrm{~h}$ for $\mathrm{H}_{2} \mathrm{O}_{2}$. At a solar zenith angle of $70^{\circ}$, steady state mixing ratios were reached within 10,7 and $52 \mathrm{~h}$ for $\mathrm{HCHO}, \mathrm{RO}_{\mathrm{x}}$ and $\mathrm{H}_{2} \mathrm{O}_{2}$, respectively. For larger solar zenith angles a steady state $\mathrm{HCHO}, \mathrm{RO}_{\mathrm{x}}$ and $\mathrm{H}_{2} \mathrm{O}_{2}$ mixing ratio could not be reached at all. Therefore, the simulations are limited to time periods during which the solar zenith angle is less than $70^{\circ}(08: 15-18: 15$ UTC), and each model simulation continues for 10 days, to ensure that steady state is achieved,.

Running the model for 10 days instead of the above defined steady state time does not lead to significantly different results, since the mixing ratios of $\mathrm{HCHO}, \mathrm{RO}_{\mathrm{x}}$ and $\mathrm{H}_{2} \mathrm{O}_{2}$ do not change much after this point. For $\mathrm{RO}_{\mathrm{x}}$ and $\mathrm{HCHO}$ the difference between the above defined steady state concentration and the concentration after 10 days of simulation is smaller than $1 \%$. For $\mathrm{H}_{2} \mathrm{O}_{2}$ differences up to $8 \%$ at high solar zenith angles can be found.

\subsubsection{Reference run}

The $\mathrm{RO}_{\mathrm{x}}$ mixing ratio calculated by the model without heterogeneous chemistry, for the period 29 July to 15 August 2002, is shown in Fig. 3a. $\mathrm{RO}_{\mathrm{x}}$ is the sum of $\mathrm{HO}_{2}, \mathrm{CH}_{3} \mathrm{O}_{2}$, higher organic peroxy radicals with up to $4 \mathrm{C}$ atoms and 


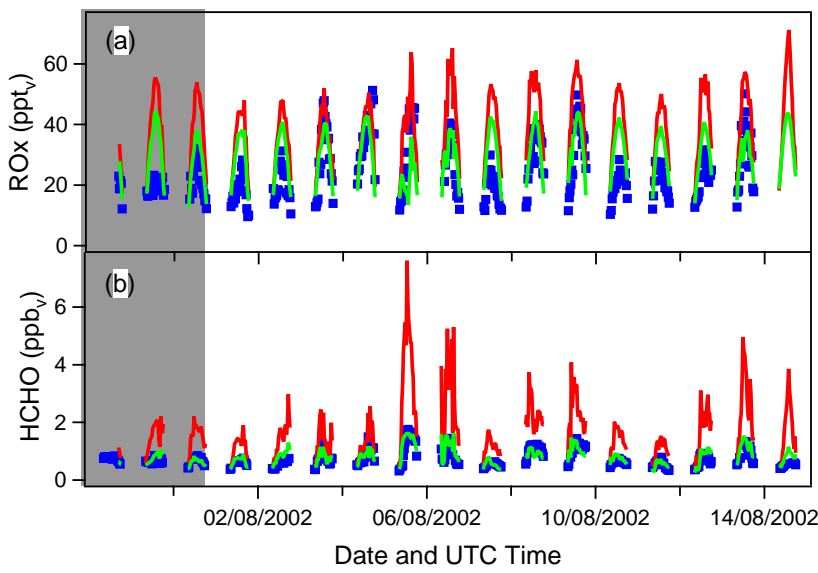

Fig. 3. Observed (blue dots) and modelled (red solid line, reference run) $\mathrm{RO}_{\mathrm{x}}$ and $\mathrm{HCHO}$ mixing ratios. The green solid line represents the model calculation without isoprene. The major Saharan dust event is marked by the grey area.

peroxy radicals formed during isoprene degradation. The main constituents of the modelled $\mathrm{RO}_{\mathrm{x}}$ are $\mathrm{HO}_{2}(60 \%)$, $\mathrm{CH}_{3} \mathrm{O}_{2}(18 \%)$ and the peroxy radicals from isoprene degradation $(16 \%)$. The contribution of other higher organic peroxy radicals to the total $\mathrm{RO}_{\mathrm{x}}$ is very small, on average $\mathrm{C}_{2} \mathrm{H}_{5} \mathrm{O}_{2}$ contributes $0.06 \%$ to the total modelled $\mathrm{RO}_{\mathrm{x}}$, $\mathrm{C}_{2} \mathrm{H}_{3} \mathrm{O}_{3} 5.6 \%, \mathrm{C}_{3} \mathrm{H}_{7} \mathrm{O}_{2} 0.01 \%, \mathrm{C}_{3} \mathrm{H}_{6} \mathrm{O}_{2} 0.17 \%, \mathrm{C}_{3} \mathrm{H}_{5} \mathrm{O}_{3}$ $0.08 \%, \mathrm{C}_{4} \mathrm{H}_{9} \mathrm{O}_{2} 0.02 \%$ and $\mathrm{C}_{4} \mathrm{H}_{9} \mathrm{O}_{4} 0.003 \%$. The $\mathrm{RO}_{\mathrm{x}}$ mixing ratio is clearly overestimated by the model, and the mean ratio of the calculated to the observed $\mathrm{RO}_{\mathrm{x}}$ mixing ratio $\left(\mathrm{RO}_{\mathrm{x}}\right.$ calc/obs) is 1.70 .

Figure $3 \mathrm{~b}$ shows the calculated and observed HCHO mixing ratios. The $\mathrm{HCHO}$ mixing ratios are also strongly overestimated by the model. The daytime maximum HCHO mixing ratio calculated by the model ranges between 1.5 and $7.5 \mathrm{ppb}_{\mathrm{v}}$, while the observed values vary between 0.7 and $1.7 \mathrm{ppb}_{\mathrm{v}}$. The mean ratio of the calculated to observed $\mathrm{HCHO}$ mixing ratio (HCHO calc/obs) equals 2.29, however, a good correlation can be found between the observed and calculated HCHO mixing ratios. When fitting a straight line through the data points, the correlation coefficient $r$ is 0.80 .

Possible reasons for the model overestimation of both the $\mathrm{RO}_{\mathrm{x}}$ and $\mathrm{HCHO}$ mixing ratios could either be an underestimation of the observed $\mathrm{HCHO}$ and $\mathrm{RO}_{\mathrm{x}}$ mixing ratios, an overestimation of the precursor gas concentrations, which are used as input for the calculations or unknown model errors. Moreover, the assumption that the airmass is in steady state might be erroneous.

A comparison of the $\mathrm{HCHO}$ and $\mathrm{RO}_{\mathrm{x}}$ mixing ratios with a previous measurement campaign at Izaña shows that the $\mathrm{HCHO}$ mixing ratios are a factor 2 lower than those observed nine years earlier, however, during this campaign the $\mathrm{HCHO}$ measurements were probably overestimated due to a spectral interference to $\mathrm{CH}_{4}$ (Fischer et al., 1998). The $\mathrm{RO}_{\mathrm{x}}$ mixing
Table 4. Calculated $\mathrm{RO}_{\mathrm{x}}$ and $\mathrm{HCHO}$ mixing ratios and calculated/observed ratios for the sensitivity runs in which the mixing ratio of the trace gas in column 1 has been reduced by a factor 2 compared to the reference run.

\begin{tabular}{lcccc}
\hline & $\begin{array}{c}\mathrm{RO}_{\mathrm{x}} \\
\left(\mathrm{ppt}_{\mathrm{v}}\right)\end{array}$ & $\begin{array}{c}\mathrm{RO}_{\mathrm{x}} \\
\text { calc/obs }\end{array}$ & $\begin{array}{c}\mathrm{HCHO} \\
\left(\mathrm{ppb}_{\mathrm{v}}\right)\end{array}$ & $\begin{array}{c}\mathrm{HCHO} \\
\text { calc/obs }\end{array}$ \\
\hline Reference run & 40 & 1.70 & 1.81 & 2.29 \\
$\mathrm{O}_{3}$ & 36 & 1.52 & 1.63 & 2.03 \\
$\mathrm{CO}$ & 41 & 1.72 & 1.86 & 2.34 \\
$\mathrm{H}_{2} \mathrm{O}$ & 37 & 1.58 & 1.69 & 2.12 \\
$\mathrm{NO}$ & 38 & 1.62 & 1.22 & 1.55 \\
Methanol & 40 & 1.70 & 1.80 & 2.27 \\
Acetone & 40 & 1.69 & 1.80 & 2.27 \\
$\mathrm{HNO}_{3}$ & 40 & 1.70 & 1.81 & 2.28 \\
$\mathrm{H}_{2} \mathrm{O}_{2}$ & 40 & 1.67 & 1.79 & 2.25 \\
$\mathrm{CH}_{3} \mathrm{OOH}$ & 39 & 1.65 & 1.72 & 2.16 \\
$\mathrm{Isprene}$ & 36 & 1.53 & 1.43 & 1.83 \\
$\mathrm{NMHC}$ & 40 & 1.70 & 1.81 & 2.28 \\
\hline
\end{tabular}

ratios are similar considering the large uncertainty in the $\mathrm{RO}_{\mathrm{x}}$ measurements (see Table 3). The influence of the input concentrations of different precursor gases for $\mathrm{HCHO}$ and $\mathrm{RO}_{\mathrm{x}}$ will be studied in the next section.

\subsubsection{Sensitivity simulations}

To investigate the effects of a range of model input parameters, several sensitivity studies have been performed in which the mixing ratio of one trace gas has been reduced by a factor two compared to the reference run. The results are summarised in Table 4.

The calculated $\mathrm{RO}_{\mathrm{x}}$ mixing ratio is rather insensitive to the changes in the input mixing ratios of most trace gases, except for $\mathrm{O}_{3}$ and $\mathrm{H}_{2} \mathrm{O}$, which are direct precursors of $\mathrm{HO}_{2}$, and for isoprene, which is a main precursor for different organic peroxides. Since the organic peroxy radicals, not originating from isoprene, contribute only $6 \%$ to the total peroxy radical mixing ratio, changes in the higher hydrocarbon concentrations do not have a significant effect on the calculated $\mathrm{RO}_{\mathrm{x}}$ mixing ratio.

The simulated $\mathrm{HCHO}$ mixing ratio is more variable, and especially sensitive to the input concentration of NO. A reduction of the $\mathrm{NO}$ mixing ratio by a factor 2 causes the $\mathrm{HCHO}$ mixing ratio to decrease by $33 \%$. At low NO mixing ratios the production of $\mathrm{HCHO}$ mainly occurs via the reaction of $\mathrm{HO}_{2}$ with $\mathrm{CH}_{3} \mathrm{O}_{2}$ and the subsequent photolysis of $\mathrm{CH}_{3} \mathrm{OOH}$, while at higher $\mathrm{NO}$ mixing ratios, the $\mathrm{HCHO}$ production is dominated by the faster reaction of $\mathrm{CH}_{3} \mathrm{O}_{2}$ with $\mathrm{NO}$, leading to an enhanced production of $\mathrm{HCHO}$.

The simulated HCHO mixing ratio is also sensitive to the input concentration of isoprene $(21 \%$ reduction of $\mathrm{HCHO}$ when the isoprene mixing ratio is reduced with a factor 2 ), 

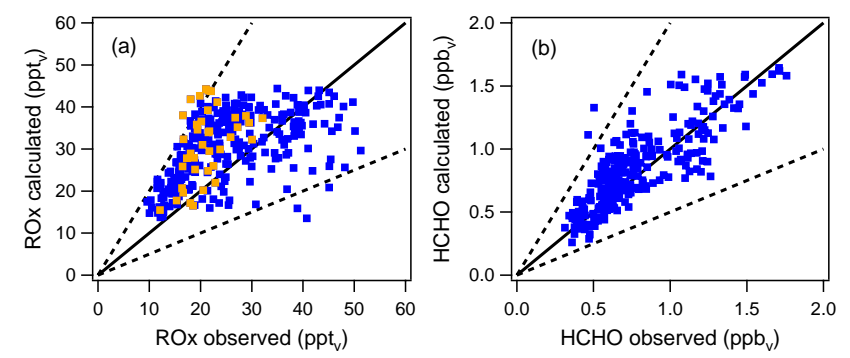

Fig. 4. Comparison between the calculated and observed $\mathrm{RO}_{\mathrm{x}}(\mathbf{a})$ and $\mathrm{HCHO}$ (b) mixing ratios (blue dots) for the model run without isoprene. The orange dots represent the $\mathrm{RO}_{\mathrm{x}}$ mixing ratios during the major Saharan dust event. The solid black line represents the 1:1 relationship, the dashed lines the 1:2 and 2:1 relationships.

$\mathrm{O}_{3}(10 \%), \mathrm{H}_{2} \mathrm{O}(7 \%)$ and $\mathrm{CH}_{3} \mathrm{OOH}(5 \%)$. Isoprene and $\mathrm{CH}_{3} \mathrm{OOH}$ are precursor gases of $\mathrm{HCHO}$, so a reduction in the mixing ratio of these trace gases will directly result in a reduced $\mathrm{HCHO}$ production. $\mathrm{O}_{3}$ and $\mathrm{H}_{2} \mathrm{O}$ influence the $\mathrm{HCHO}$ mixing ratio through the change in $\mathrm{OH}$ mixing ratio. If the concentration of $\mathrm{O}_{3}$ or $\mathrm{H}_{2} \mathrm{O}$ is reduced, less $\mathrm{OH}$ is produced via the reaction of $\mathrm{H}_{2} \mathrm{O}$ with $\mathrm{O}^{1} \mathrm{D}$ and less $\mathrm{OH}$ will be available for the destruction of VOCs and notably isoprene, which results in a reduced production of $\mathrm{HCHO}$.

The above described sensitivity studies show that the $\mathrm{RO}_{\mathrm{x}}$ and $\mathrm{HCHO}$ mixing ratios are most sensitive to the mixing ratio of $\mathrm{NO}, \mathrm{O}_{3}, \mathrm{H}_{2} \mathrm{O}, \mathrm{CH}_{3} \mathrm{OOH}$ and isoprene. From these gases, the measurement uncertainty, and hence the uncertainty of the boxmodel input mixing ratios, of isoprene and $\mathrm{CH}_{3} \mathrm{OOH}$ is the largest.

As has been discussed in the observations section, the isoprene mixing ratio is probably determined by emissions close to the measurement station. Therefore, the airmass may not have reached equilibrium with respect to isoprene. We intend to calculate the equivalent isoprene mixing ratio, which corresponds to the observed $\mathrm{HCHO}$ and $\mathrm{RO}_{\mathrm{x}}$ mixing ratios. While doing so we found that a simulation without taking isoprene into account provides the best agreement with the measurements, indicating that isoprene may not have a significant effect on the observed $\mathrm{HCHO}$ and $\mathrm{RO}_{\mathrm{x}}$ mixing ratio and that the effect of the emissions of isoprene (and other biogenic compounds) on the HCHO budget will first show up during further evolution of the airmass.

Moreover, the isoprene mixing ratios observed during MINATROC were high relative to the isoprene mixing ratios observed during the OCTA campaign at Izaña in July/August 1993 (Fischer et al., 1998). Excluding the measurements performed during the major dust event, the mean isoprene mixing ratio was $270 \pm 206 \mathrm{ppt}_{\mathrm{v}}$ during the day and below the detection limit at night. This is a factor 4.5 higher than the mean daytime isoprene mixing ratio observed during OCTA, which was $60 \pm 124$ ppt $_{\mathrm{v}}$ (Fischer et al., 1998).

Putting the isoprene mixing ratio to zero leads to decreases in both the $\mathrm{HCHO}$ and $\mathrm{RO}_{\mathrm{x}}$ mixing ratios. The mean calc/obs ratio of $\mathrm{RO}_{\mathrm{x}}$ decreases from 1.70 in the reference run to 1.31 in the run without isoprene. The contribution of the different peroxy radicals to the total $\mathrm{RO}_{\mathrm{x}}$ mixing ratio changes, since no organic peroxy radicals are formed during the isoprene degradation. The main constituents of $\mathrm{RO}_{\mathrm{x}}$ are still $\mathrm{HO}_{2}$ (72\%) and $\mathrm{CH}_{3} \mathrm{O}_{2}(26 \%$ ), while the contribution of other organic peroxy radicals decreases to $2 \%$. The effect of isoprene on the $\mathrm{HCHO}$ mixing ratio is even stronger than on $\mathrm{RO}_{\mathrm{x}}$. The calc/obs ratio of HCHO decreases from 2.29 in the reference run to 1.12 in the run without isoprene.

A detailed comparison between the observed and modelled $\mathrm{RO}_{\mathrm{x}}$ mixing ratios is shown in Fig. 4a. Here the solid line represents the ideal 1:1 relationship between the modelled and observed values, while the dashed lines correspond to a deviation of this ideal relationship by a factor of 2 , which about equals the total uncertainty of all measured parameters used as input for the model calculations. In total 304 model data points could be used for the comparison with observations, from which $97 \%$ agree within a factor of two. A straight line fit through the calculated and observed $\mathrm{RO}_{\mathrm{x}}$ mixing ratios gives a linear correlation coefficient $r$ of 0.50 .

The diurnal variation and the absolute mixing ratios of $\mathrm{HCHO}$ are captured well by the model (see Fig. 3b). On average the model slightly overestimates the HCHO mixing ratio, the mean ratio of the calculated $\mathrm{HCHO}$ mixing ratio to the observed HCHO mixing ratio (HCHO calc/obs) is 1.12. From the 272 data points, $99 \%$ of the calculated HCHO mixing ratios are within a factor two of the observed HCHO mixing ratios (see Fig. 4b). Moreover, a good correlation is found between the observed and calculated $\mathrm{HCHO}$ mixing ratios. When fitting a straight line through the data points in Fig. 4b, the correlation coefficient $r$ is 0.82 .

Previous model studies using three dimensional global chemistry-transport or boxmodels have also investigated the HCHO budget. The comparison between modelled and observed $\mathrm{HCHO}$ concentrations provides very different results. In the remote marine boundary layer (Ayers et al., 1997; Weller et al., 2000) and the upper free troposphere (Kormann et al., 2003; Jaegle et al., 2000) models tend to underestimate the concentration of HCHO. For the above mentioned marine boundary layer calculations this could at least partly be explained by a lack of higher hydrocarbons in the model, however, for the upper troposphere including higher hydrocarbons did not reproduce the high concentrations observed. For the polluted marine boundary layer and the lower free troposphere $\mathrm{HCHO}$ mixing ratios are generally overestimated by models (e.g. Wagner et al. 2002; Zhou et al., 1996). Possible explanations for the overprediction of $\mathrm{HCHO}$ by models are deficiencies in considering dry deposition, multiphase chemistry in aerosols and clouds or halogen chemistry in the marine boundary layer. On the other hand, Olson et al. (2004) found a good agreement between observed and modelled HCHO mixing ratios between 60 and 500 ppt $_{\mathrm{v}}$ in the free troposphere. At higher $\mathrm{HCHO}$ concentrations the model increasingly underpredicts $\mathrm{HCHO}$, which could be explained by the transport of very polluted airmasses. 
To investigate the effect of dry deposition in our simulations we included a sinusoidal dry deposition rate for $\mathrm{HCHO}$ analogous to $\mathrm{H}_{2} \mathrm{O}_{2}$, which is explained in detail in the next section. A noon time maximum dry deposition rate of $8.4 \times 10^{-7} \mathrm{~s}^{-1}$ is necessary to achieve good agreement between the calculated and observed HCHO mixing ratios. This is more than the dry deposition rate necessary to explain the $\mathrm{H}_{2} \mathrm{O}_{2}$ measurements (see next section). Based on the difference in solubility and reactivity, the dry deposition velocity of $\mathrm{H}_{2} \mathrm{O}_{2}$ should at least be a factor 2 higher than HCHO (L. Ganzeveld, pers. comm., 2004), hence dry deposition can only partly explain the difference between model and observations.

\subsubsection{Discussion}

In this section we will discuss if the setup of the boxmodel is appropriate for the model simulations which are presented in this work. We will focus on the following three questions. Is it realistic to assume that the airmass is in steady state, when it takes the model up to $10 \mathrm{~h}$ to reach a steady state mixing ratio for $\mathrm{HCHO}$ and $\mathrm{RO}_{\mathrm{x}}$ ? Wouldn't it be more appropriate to include a diurnal cycle of the photolysis rates, so that the photochemical components are simulated in a more realistic way? Why is the temporal development of the trace gases not taken into account during the simulations?

The model is used to calculate steady state concentrations and not to simulate the history of the airmass. By keeping the concentrations of relatively long lived trace gases and the photolysis rates constant we tried to simulate the "potential" concentrations of the gases when the airmass would have been in photochemical steady state. So we do not intend to perform a lagrangian simulation.

The definition of steady state time used in this paper is very harsh. Compared to the uncertainty of the measurements and the model a change of 1 in $30 \mathrm{~min}$ is very small. Nevertheless, steady state mixing ratios of $\mathrm{HCHO}$ and $\mathrm{RO}_{\mathrm{x}}$ could be reached within a day.

The airmasses arriving at the measurement station originate partly from the free troposphere and partly from the marine boundary layer. On average the contribution of the marine boundary layer was $17 \%$. It is realistic to assume that the mixing ratios of the long lived trace gases, which are used as input for the boxmodel, in the free tropospheric airmass do not change dramatically within $6-10 \mathrm{~h}$. The marine boundary layer airmass, however, is subject to anthropogenic emissions in the coastal area and to biogenic emissions closer to the measurement site. We could show that the airmass was probably not in steady state with respect to isoprene, which has been emitted close to the measurement station, and that removing isoprene from the calculations did improve the agreement between observations and boxmodel calculations. Considering the average wind speed and wind direction of the measurement station during MINATROC, the average transport time of the airmass from the marine

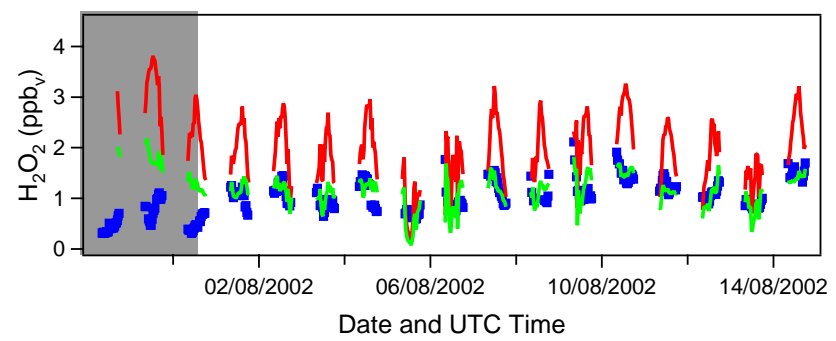

Fig. 5. Observed (blue dots) and calculated (red solid lines) $\mathrm{H}_{2} \mathrm{O}_{2}$ mixing ratios for the model run in which the mixing ratios of $\mathrm{H}_{2} \mathrm{O}_{2}$ are not fixed to the observed values. The green solid line represents the model run in which dry deposition of $\mathrm{H}_{2} \mathrm{O}_{2}$ is included. The major Saharan dust event is marked by the grey area.

boundary layer to the measurement station is estimated to be $1.5 \mathrm{~h}$. After $1.5 \mathrm{~h}$ of simulation the $\mathrm{RO}_{\mathrm{x}}$ mixing ratio reached $93 \%$ of its end mixing ratio (after 10 days of simulation) and HCHO 69\%. Taking into account the average contribution of marine boundary layer air of $17 \%$, we estimated an uncertainty of $5 \%$ and $1 \%$ for $\mathrm{HCHO}$ and $\mathrm{RO}_{\mathrm{x}}$, respectively, due to this possible non steady state.

These numbers also show the uncertainty of the model simulations early during the day. $1.5 \mathrm{~h}$ after sunrise the steady state $\mathrm{RO}_{\mathrm{x}}$ mixing ratio was reached by $93 \%$ and $\mathrm{HCHO}$ by $69 \%$ providing an uncertainty of $7 \%$ and $31 \%$ for $\mathrm{RO}_{\mathrm{x}}$ and $\mathrm{HCHO}$, respectively. Note that the first simulations we presented were at 08:15 UTC, which is about $2 \mathrm{~h}$ after sunrise.

In a further development of the boxmodel a diurnal cycle of the photolysis rates has been implemented, analogous to the work of Olson et al. (2004), to account for the diurnal cycle of photochemical components. From these simulations a diurnal steady state mixing ratio can be determined. With this setup of the model the NO mixing ratio cannot be fixed but a diurnal emission pattern had to be included so that the resulting NO concentration was similar to the observed concentration. First tests with the new setup of the model for another measurement campaign, did not show large differences between the two approaches (fixed photolysis rates or a diurnal cycle in the photolysis rates), however this comparison has been done for a single model run in the upper troposphere, and provides no statistically significant results.

\subsubsection{Simulation of hydrogen peroxide}

Since we focus on the ability of the model to simulate observed $\mathrm{H}_{2} \mathrm{O}_{2}$ mixing ratios, a model simulation has been performed in which $\mathrm{H}_{2} \mathrm{O}_{2}$ is not fixed to the measured mixing ratio but has been calculated freely by the model. For this, the model run without isoprene is taken as a reference. The results of this simulation are shown in Fig. 5. The $\mathrm{H}_{2} \mathrm{O}_{2}$ mixing ratio calculated by the model is much higher than the observed $\mathrm{H}_{2} \mathrm{O}_{2}$ mixing ratio $\left(\mathrm{H}_{2} \mathrm{O}_{2}\right.$ calc/obs $\left.=2.16\right)$. This is 
mainly due to the fact that dry deposition of $\mathrm{H}_{2} \mathrm{O}_{2}$ at the surface is not included in the model.

The discrepancy between the calculated and observed values is largest during the Saharan dust event. Due to the high relative humidity observed during this period, relatively high $\mathrm{H}_{2} \mathrm{O}_{2}$ mixing ratios are calculated, while much lower mixing ratios were observed. Excluding the dust data points from the total dataset gives a much better agreement between observed and calculated values. For the dust-poor period, the mean calc/obs ratio of $\mathrm{H}_{2} \mathrm{O}_{2}$ is 1.75 .

To improve the agreement between the observed and modelled values, we included a sinusoidal dry deposition rate for $\mathrm{H}_{2} \mathrm{O}_{2}$ in the model, with the highest deposition rate at local noon, when the upslope winds and turbulent exchange in the boundary layer are relatively strong. Dry deposition was parameterised such that after each steady state calculation the concentration of $\mathrm{H}_{2} \mathrm{O}_{2}$ was reduced according to this dry deposition rate. A calc/obs ratio of $\mathrm{H}_{2} \mathrm{O}_{2}$ of one was obtained (for the dust-poor period) when a maximum dry deposition rate of $6.5 \times 10^{-7} \mathrm{~s}^{-1}$ at local noon was assumed, corresponding to a removal fraction of $56 \%$. For the complex meteorological situation at the measurement station with mixing of boundary layer air, which is subject to dry deposition and free tropospheric air, which is likely not influenced by dry deposition, it is difficult to translate this dry deposition rate into a deposition velocity. The results of this simulation are also presented in Fig. 5. From this figure it is clear that even if dry deposition is included in the model calculations, the $\mathrm{H}_{2} \mathrm{O}_{2}$ mixing ratio is still strongly overestimated during the major Saharan dust event. A reason for this may be the uptake of $\mathrm{H}_{2} \mathrm{O}_{2}$ and/or $\mathrm{HO}_{2}$ on the surface of the dust aerosols, which will be investigated in the next section.

\subsection{Heterogeneous chemistry}

The observations during the Saharan dust event show reduced mixing ratios of $\mathrm{RO}_{\mathrm{x}}$ and $\mathrm{H}_{2} \mathrm{O}_{2}$. The reduced $\mathrm{H}_{2} \mathrm{O}_{2}$ mixing ratios could not be explained by gas phase chemistry or through the reduction in photolysis rates. Even after including dry deposition the model strongly overestimates the $\mathrm{H}_{2} \mathrm{O}_{2}$ mixing ratios during the dust event. Also the $\mathrm{RO}_{\mathrm{x}}$ mixing ratios are overestimated by the (gas phase) model during the dust event, however, there is no clear relation with the presence of Saharan dust. To investigate the influence of Saharan dust aerosol particles on the mixing ratio of peroxy radicals and hydrogen peroxide, heterogeneous uptake reactions of $\mathrm{HO}_{2}$ and $\mathrm{H}_{2} \mathrm{O}_{2}$ have been included in the model. Note that radiation effects of mineral dust aerosol have been accounted for by the scaling of the photolysis rates to the observed $\mathrm{JNO}_{2}$ value.

\subsubsection{Heterogeneous removal reactions}

The removal rate of gas-phase species $\mathrm{j}$ by aerosol particles can be described by a pseudo-first-order rate coefficient $\mathrm{k}_{j}$ $\left(\mathrm{s}^{-1}\right)$, given by Heikes and Thompson (1983):

$k_{j}=\int_{r 1}^{r 2} k_{d, j}(r) n(r) d r$

where $n(r) d r\left(\mathrm{~cm}^{-3}\right)$ represents the number concentration of particles with a radius between $r$ and $r+d r$, and $k_{d, j}(r)$ is the size dependent mass transfer coefficient $\left(\mathrm{cm}^{3} \mathrm{~s}^{-1}\right)$, which can be calculated using the Fuchs and Sutugin (1970) interpolation equation:

$k_{d, j}=\frac{4 \pi D_{j} V}{1+K n(x+4(1-\alpha) / 3 \alpha)}$

where $D_{j}\left(\mathrm{~cm}^{2} \mathrm{~s}^{-1}\right)$ is the gas phase molecular diffusion coefficient of species $j, V$ the ventilation coefficient, which is close to unity, and $K n$ the dimensionless Knudsen number, defined as the ratio of the effective mean free path of a gas molecule in air, $\lambda$, to the particle radius $r . \alpha$ is the mass accommodation coefficient, a dimensionless number defined as the number of molecules adsorbed by the surface of an aerosol divided by the number of collisions with the aerosol; $x$ represents a correction factor for anisotropic movement and is dependent on the Knudsen number (Fuchs and Sutugin, 1970).

In the laboratory much effort has been undertaken to determine the reactive uptake coefficient $(\gamma)$ of different atmospheric gases on mineral dust aerosol (e.g. Usher et al., 2003; Hanisch and Crowley, 2003; Underwood et al., 2001). The reactive uptake coefficient represents the fraction of collisions with a particle that leads to irreversible loss of the gas (thus including chemical reactions). For the calculation of the heterogeneous removal rate the accommodation coefficient $\alpha$ needs to be known, denoting the probability that a gas molecule, colliding with an aerosol particle, will be (physically) incorporated into the particle. Since we do not explicitly account for chemical reactions in the condensed phase, we substitute $\alpha$ by $\gamma$. Since $\gamma$ is a measure for the net transfer of the species to the aerosol particle, $\alpha$ represents an upper limit of $\gamma$.

Unfortunately no laboratory studies of the uptake of the $\mathrm{HO}_{2}$ radical on mineral dust aerosol are documented, however, a few studies are performed to determine the uptake of $\mathrm{HO}_{2}$ on different types of surfaces. Hanson et al. (1992), for example, determined the uptake of $\mathrm{HO}_{2}$ on a water and sulphuric acid surface and found reactive uptake coefficients of $>0.01$ and $>0.05$, respectively, while Cooper and Abbatt (1996) measured net uptake coefficients for $\mathrm{HO}_{2}$ radicals on supercooled sulphuric acid water-ice surfaces of 0.055 and 0.025 , respectively. The presence of free $\mathrm{Cu}$ ions in the aerosol enhances the uptake of $\mathrm{HO}_{2}$ on aqueous surfaces significantly (Mozurkewich et al., 1987). In a review Jacob (2000) concludes that the uptake of $\mathrm{HO}_{2}$ by aqueous aerosols takes place with a $\gamma$ of $0.1-1$, and he recommends including the uptake of $\mathrm{HO}_{2}$ by aerosols with $\gamma=0.2$ in atmospheric 
chemistry models. This is also the value of $\gamma$ we deploy in this study. The author also concludes that although the mechanism for $\mathrm{HO}_{2}$ uptake is uncertain, $\mathrm{H}_{2} \mathrm{O}_{2}$ is the likely product (Jacob, 2000).

Even fewer laboratory studies have been conducted on the uptake of $\mathrm{H}_{2} \mathrm{O}_{2}$ on different types of surfaces. Worsnop et al. (1989) determined the mass accommodation coefficient of $\mathrm{H}_{2} \mathrm{O}_{2}$ on aqueous surfaces. They found a strong negative temperature dependence of the mass accommodation coefficient, with an uptake coefficient of $0.18 \pm 0.02$ at $273 \mathrm{~K}$. Clegg and Abbatt (2001) determined the absolute uptake of $\mathrm{H}_{2} \mathrm{O}_{2}$ on an ice surface to be $4 \times 10^{9}$ molecules $\mathrm{cm}^{-2}$, at an average ambient $\mathrm{H}_{2} \mathrm{O}_{2}$ mixing ratio of about $1 \mathrm{ppb}_{\mathrm{v}}$. For the maximum aerosol surface area of $500 \mu \mathrm{m}^{2} / \mathrm{cm}^{3}$ observed during the major Saharan dust event during MINATROC, this will cause a negligible decrease in $\mathrm{H}_{2} \mathrm{O}_{2}$ mixing ratio of much less than $1 \%$. To our knowledge no laboratory studies on the uptake of $\mathrm{H}_{2} \mathrm{O}_{2}$ on mineral dust aerosol have been performed, therefore, different uptake coefficients will be tested in this study, starting with the value of 0.18 .

The heterogeneous removal rate for $\mathrm{HO}_{2}$ and $\mathrm{H}_{2} \mathrm{O}_{2}$ has been calculated off-line using the observed aerosol size distribution, temperature and pressure. For this, the complete size range from $6 \mathrm{~nm}$ to $10 \mu \mathrm{m}$ has been taken into account.

Trajectory analyses indicate that the dust-loaded airmasses travelled about 3 days from the source region in Africa (western Algeria and Mauritania) to the measurement station. To calculate a realistic uptake coefficient we have to use a realistic time for dust uptake. Therefore, heterogeneous removal reactions were only activated the last three days of the simulation. We realise that here we mix up the steady state and lagrangian approach of the boxmodel.

\subsubsection{Results of heterogeneous chemistry calculations}

To find the accommodation coefficient for the heterogeneous uptake of $\mathrm{H}_{2} \mathrm{O}_{2}$ on Saharan dust particles we altered the $\mathrm{H}_{2} \mathrm{O}_{2}$ accommodation coefficient until the calc/obs ratio of $\mathrm{H}_{2} \mathrm{O}_{2}$ was equal to one. For this all data points starting at 29 July were used and dry deposition, as described in Sect. 6.2.3, was included. When the uptake coefficient for aqueous surfaces is used $(\gamma=0.18)$ almost all $\mathrm{H}_{2} \mathrm{O}_{2}$ is scavenged and the calc/obs ratio of $\mathrm{H}_{2} \mathrm{O}_{2}$ decreases to 0.04. A calc/obs ratio of $\mathrm{H}_{2} \mathrm{O}_{2}$ of one was found for a much lower accommodation coefficient, $5 \times 10^{-4}$. The corresponding average removal rate of $\mathrm{H}_{2} \mathrm{O}_{2}, k_{j}$, during the major dust event was $8 \times 10^{-6} \mathrm{~s}^{-1}$. The results of the simulation with this accommodation coefficient are shown in Fig. 6a. From the 265 data points $93 \%$ of the modelled $\mathrm{H}_{2} \mathrm{O}_{2}$ mixing ratios were within a factor of 2 of the observed mixing ratio.

The influence of the reduced $\mathrm{H}_{2} \mathrm{O}_{2}$ mixing ratios on $\mathrm{RO}_{\mathrm{x}}$ appears to be relatively small; the calc/obs ratio of $\mathrm{RO}_{\mathrm{x}}$ decreases from 1.38 in the run without heterogeneous removal reactions to 1.36 in the run with $\mathrm{H}_{2} \mathrm{O}_{2}$ scavenging. Hence, the reduced $\mathrm{RO}_{\mathrm{x}}$ mixing ratios observed during the dust event
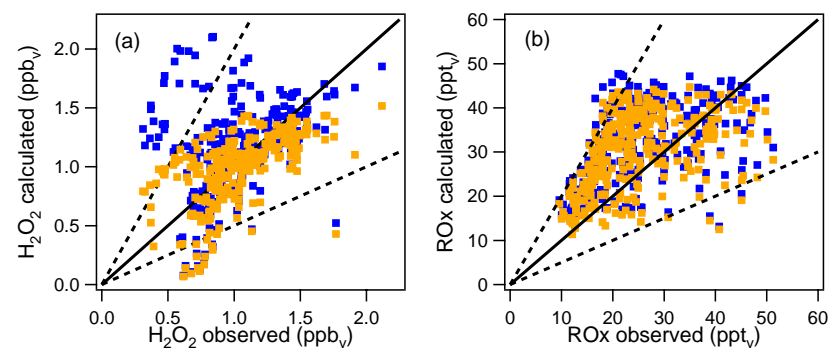

Fig. 6. Comparison between the calculated and observed $\mathrm{H}_{2} \mathrm{O}_{2}$ and $\mathrm{RO}_{\mathrm{x}}$ mixing ratios (blue dots). The orange dots represent the model run including heterogeneous removal of (a) $\mathrm{H}_{2} \mathrm{O}_{2}\left(\gamma=5 \times 10^{-4}\right)$ and (b) $\mathrm{HO}_{2}(\gamma=0.2)$ on Saharan dust aerosol. The solid black line represents the 1:1 relationship, the dashed lines the $1: 2$ and 2:1 relationships.

cannot be explained by heterogeneous removal of $\mathrm{H}_{2} \mathrm{O}_{2}$ on Saharan dust aerosol. Therefore, we investigated the effect of heterogeneous removal of $\mathrm{HO}_{2}$ on Saharan dust particles on the $\mathrm{RO}_{\mathrm{x}}$ mixing ratio. For this an uptake coefficient of 0.2 is assumed, according to the recommendation of Jacob (2000), corresponding to a first order rate coefficient, $k_{j}$, of $2 \times 10^{-3} \mathrm{~s}^{-1}$ during the major dust event. Two simulations were performed: one in which the $\mathrm{HO}_{2}$ is irreversibly removed by the dust aerosols, and one in which one molecule of $\mathrm{H}_{2} \mathrm{O}_{2}$ is produced on the surface of a dust particle for each molecule $\mathrm{HO}_{2}$ which is taken up.

In spite of the relatively high uptake coefficient, heterogeneous removal of $\mathrm{HO}_{2}$ causes only a small decrease in the $\mathrm{RO}_{\mathrm{x}}$ mixing ratio. The calc/obs ratio of $\mathrm{RO}_{\mathrm{x}}$ decreases from 1.38 in the run without heterogeneous removal reactions to 1.30 in the run with heterogeneous removal of $\mathrm{HO}_{2}$ (see Fig. 6b). Even when an uptake coefficient of 1 is assumed the model still overestimates the $\mathrm{RO}_{\mathrm{x}}$ mixing ratio $\left(\mathrm{RO}_{\mathrm{x}}\right.$ calc/obs=1.14). The relatively small change in the calculated $\mathrm{RO}_{\mathrm{x}}$ mixing ratio indicates that the heterogeneous removal reaction of $\mathrm{HO}_{2}$ is slow compared to the fast gas phase production and destruction reactions of $\mathrm{HO}_{2}$. The effect of heterogeneous removal of $\mathrm{HO}_{2}$ on the $\mathrm{H}_{2} \mathrm{O}_{2}$ mixing ratio, however, is very strong. The $\mathrm{H}_{2} \mathrm{O}_{2}$ mixing ratio decreases to almost the observed value $\left(\mathrm{H}_{2} \mathrm{O}_{2}\right.$ calc/obs=1.05) when heterogeneous removal of $\mathrm{HO}_{2}$ with an uptake coefficient of 0.2 is included in the model. Hence, if no $\mathrm{H}_{2} \mathrm{O}_{2}$ is formed during the uptake reaction of $\mathrm{HO}_{2}$ on Saharan dust particles, only including heterogeneous removal of $\mathrm{HO}_{2}$ leads to a good agreement between the calculated and observed $\mathrm{H}_{2} \mathrm{O}_{2}$ mixing ratios. Note that a calc/obs ratio of $\mathrm{H}_{2} \mathrm{O}_{2}$ of exactly one is reached when heterogeneous removal of $\mathrm{H}_{2} \mathrm{O}_{2}$ with an accommodation coefficient of $7 \times 10^{-5}$ is additionally included in the model.

If we assume that $\mathrm{H}_{2} \mathrm{O}_{2}$ is formed when $\mathrm{HO}_{2}$ is taken up in the Saharan dust aerosol the $\mathrm{H}_{2} \mathrm{O}_{2}$ mixing ratio increases strongly compared to the run without heterogeneous chemistry, while the effect on $\mathrm{RO}_{\mathrm{x}}$ is marginal. During the major 


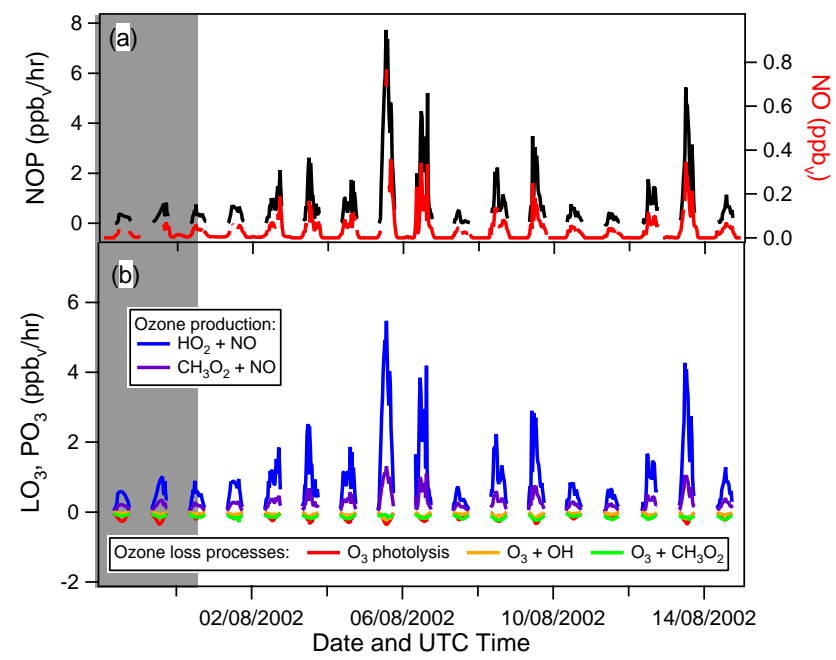

Fig. 7. Calculated net ozone production rate (NOP) for the MINATROC campaign (a) and partitioning of the different production and loss processes (b). The major Saharan dust event is marked by the grey area.

dust event the calculated $\mathrm{H}_{2} \mathrm{O}_{2}$ mixing ratio exceeds $5 \mathrm{ppb}_{\mathrm{v}}$, and an average calc/obs ratio of $\mathrm{H}_{2} \mathrm{O}_{2}$ of 1.89 is calculated. Heterogeneous removal of $\mathrm{H}_{2} \mathrm{O}_{2}$ with an accommodation coefficient of $2 \times 10^{-3}$ had to be included to restore the agreement between calculated and observed values.

\subsection{Ozone production rates}

The model calculations have been set up to calculate the steady state concentrations of relatively short lived trace gases, while the observed mixing ratios of longer lived species, including ozone, were used as input parameters. This precludes the comparison of calculated and observed $\mathrm{O}_{3}$ mixing ratios, and drawing conclusions about for example ozone uptake on Saharan dust particles. This would require a model calculation along a back-trajectory, however, the concentration values needed to constrain the model over the dust source region are not available.

Instead, we focus on the calculation of the net ozone production rate (NOP) during the campaign, to try to explain the low ozone mixing ratios observed during the major dust event by changes in the ozone production and loss rates. The method to determine the NOP has been introduced by Liu et al. (1980) and is summarised below. A detailed description of the procedure can also be found in Fischer et al. (2003) for the first part of the MINATROC project.

The net ozone production rate can be described as the difference between the ozone production $\left(\mathrm{PO}_{3}=\left\{k_{1}\left[\mathrm{HO}_{2}\right]+k_{2}\left[\mathrm{CH}_{3} \mathrm{O}_{2}\right]\right\}[\mathrm{NO}]\right)$ and loss rates $\left(\mathrm{LO}_{3}=\left(f \times \mathrm{JO}^{1} \mathrm{D}+k_{3}[\mathrm{OH}]+k_{4}\left[\mathrm{HO}_{2}\right]\right) \quad\left[\mathrm{O}_{3}\right]\right), \quad$ where $k_{1}$ and $k_{2}$ are the reaction rates of the reaction of $\mathrm{NO}$ with $\mathrm{HO}_{2}$ and $\mathrm{CH}_{3} \mathrm{O}_{2}$, respectively, $f$ is the fraction of $\mathrm{O}^{1} \mathrm{D}$ atoms reacting with $\mathrm{H}_{2} \mathrm{O}$ to produce $\mathrm{OH}$ rather than being deactivated through collisions with air molecules, $\mathrm{JO}^{1} \mathrm{D}$ is the photolysis rate of $\mathrm{O}_{3}$, and $k_{3}$ and $k_{4}$ are the reaction rates of the reaction of $\mathrm{O}_{3}$ with $\mathrm{OH}$ and $\mathrm{HO}_{2}$, respectively. In this approach, it is assumed that ozone loss due to dry deposition, heterogeneous reactions, uptake in cloud droplets and reactions with unsaturated VOCs are negligible.

The mixing ratios of $\mathrm{NO}, \mathrm{O}_{3}, \mathrm{H}_{2} \mathrm{O}$ (needed to calculate $\mathrm{f}$ ) and the ozone photolysis rate were measured during MINATROC, while the $\mathrm{OH}, \mathrm{HO}_{2}$ and $\mathrm{CH}_{3} \mathrm{O}_{2}$ mixing ratios were calculated by the model (the run without isoprene is used here). The net ozone production rate is shown in Fig. 7a, and ranges between 0 and $7 \mathrm{ppb}_{\mathrm{v}} / \mathrm{hr}$. During the major dust event relatively low ozone production rates are calculated. The daytime mean NOP is $0.33 \pm 0.24 \mathrm{ppb}_{\mathrm{v}} / \mathrm{hr}$ during the major dust event and $1.06 \pm 1.37 \mathrm{ppb}_{\mathrm{v}} / \mathrm{hr}$ in the dust-poor airmasses. The NOP is dominated by the primary production of $\mathrm{O}_{3}$, which can be seen as a good correlation between NOP and the NO mixing ratio in Fig. 7a. This also becomes clear in Fig. 7b, where the contribution of the different production and loss processes to the NOP is shown. The reactions of $\mathrm{NO}$ with $\mathrm{HO}_{2}$ and $\mathrm{CH}_{3} \mathrm{O}_{2}$ dominate the net $\mathrm{O}_{3}$ production rate. On the other hand, the loss terms are very small. The difference between dust-loaded and dust-poor airmasses is also determined by the difference in primary ozone production through the relatively low $\mathrm{RO}_{\mathrm{x}}$ and $\mathrm{NO}$ mixing ratios in the Saharan dust airmasses.

Since the $\mathrm{RO}_{\mathrm{x}}$ mixing ratio is overestimated by the boxmodel during the dust event, the NOP is also calculated using the measured $\mathrm{RO}_{\mathrm{x}}$ values, maintaining the $\mathrm{HO}_{2} / \mathrm{RO}_{2}$ ratio as calculated by the boxmodel. Therefore, the modelled $\mathrm{HO}_{2}$ and $\mathrm{CH}_{3} \mathrm{O}_{2}$ concentrations were scaled using the calc/obs ratio of $\mathrm{RO}_{\mathrm{x}}$. When doing so, the mean daytime NOP during the dust event decreased to $0.14 \pm 0.13 \mathrm{ppb}_{\mathrm{v}} / \mathrm{hr}$, while the NOP in the dust-poor airmasses remained the same.

The relatively low $\mathrm{RO}_{\mathrm{x}}$ and $\mathrm{NO}$ mixing ratios observed during the major dust event cause a significant reduction in the net ozone production rate, however, the values remain positive. On average the difference in daytime mean $\mathrm{O}_{3}$ mixing ratio between the dust-loaded and dust-poor airmasses was $17 \mathrm{ppb}_{\mathrm{v}}$, while the difference in NOP was 0.73 and 0.92 $\mathrm{ppb}_{\mathrm{v}} / \mathrm{hr}$ for the modelled and observed $\mathrm{RO}_{\mathrm{x}}$ mixing ratios, respectively. Within 23 and $18 \mathrm{~h}$ of sunlight, respectively, a difference of $17 \mathrm{ppb}_{\mathrm{v}} \mathrm{O}_{3}$ could be achieved, which corresponds to an air mass "age" of 2 to 3 days (assuming $10 \mathrm{~h}$ sunshine per day), which is close to the estimated age of the dust-loaded airmasses. However, since the ozone mixing ratios observed in the dust-loaded airmasses are relatively low, a net ozone production of $0.14-0.33 \mathrm{ppb}_{\mathrm{v}} / \mathrm{hr}$ during the last three days would mean that the $\mathrm{O}_{3}$ mixing ratio in the source region was even lower, about $25-30 \mathrm{ppb}_{\mathrm{v}}$. The low $\mathrm{O}_{3}$ mixing ratio observed in the dust-loaded airmasses would then be attributed to the transport of $\mathrm{O}_{3}$ poor air from the North African continent to the measurement site. On the other hand, the relatively high NO mixing ratios observed at the measurement site are at least partly due to transport from the local boundary layer, and probably not representative for the 
NO mixing ratio during the last three days, which means that the airmass may have been subject to net ozone destruction during the first 2-2.5 days of its transport from the North African continent. Another possible cause for the low $\mathrm{O}_{3}$ mixing ratios observed during the Saharan dust event is heterogeneous removal of $\mathrm{O}_{3}$ on Saharan dust aerosol. Ozone destruction at the surface and cloud uptake could be important at this measurement site as well, however, it probably did not cause the difference between the $\mathrm{O}_{3}$ mixing ratio observed in the dust-loaded and dust-poor air masses, since the cloud and surface conditions did not change during the campaign.

Due to the relatively high NO mixing ratios observed on several days during the MINATROC campaign, the average net ozone production rate is high compared to other campaigns. The daily average NOP ranged between 0.15 and $3.7 \mathrm{ppb}_{\mathrm{v}} / \mathrm{hr}$, and the corresponding daily average NO mixing ratio was between 27 and $265 \mathrm{ppt}_{\mathrm{v}}$. During the first MINATROC campaign at Mt. Cimone the daytime mean NOP ranged between -0.1 and $0.3 \mathrm{ppb}_{\mathrm{v}} / \mathrm{hr}$ for an average daily mean NO mixing ratio of about $40 \mathrm{ppt}_{v}$ (Fischer et al., 2003), comparable to the days with lower NO mixing ratios at Izaña. At Mauna Loa, a mountain station at about the same latitude as Izaña, being much further away from pollution sources, net ozone destruction was found. During the summer of 1992 an average midday NOP of $-0.15 \mathrm{ppb}_{\mathrm{v}} / \mathrm{hr}$ was calculated at an average $\mathrm{NO}$ mixing ratio of $19 \mathrm{ppt}_{\mathrm{v}}$ (Cantrell et al., 1996).

\section{Summary and conclusions}

During the Saharan dust event reduced mixing ratios of $\mathrm{O}_{3}$, $\mathrm{RO}_{\mathrm{x}}, \mathrm{NO}_{\mathrm{x}}$ and $\mathrm{H}_{2} \mathrm{O}_{2}$ were observed compared to the rest of the campaign. The daytime mean $\mathrm{O}_{3}, \mathrm{NO}_{\mathrm{x}}$ and $\mathrm{H}_{2} \mathrm{O}_{2}$ mixing ratios dropped by $33 \%, 35 \%$ and $48 \%$ during the dust event, respectively, while the midday maximum $\mathrm{RO}_{\mathrm{x}}$ mixing ratio decreased by $47 \%$ compared to the dust-poor days.

Using the MECCA chemistry box model, steady state concentrations of $\mathrm{RO}_{\mathrm{x}}, \mathrm{HCHO}$ and $\mathrm{H}_{2} \mathrm{O}_{2}$ were simulated and compared to the observed mixing ratios. The observed $\mathrm{RO}_{\mathrm{x}}$ mixing ratios could be reproduced within a factor of two of the observed values, however, the variability of the modelled values was much lower than the variability in the observed mixing ratios. The calculated $\mathrm{RO}_{\mathrm{x}}$ mixing ratio appeared to be rather insensitive to changes in the input concentrations of most trace gases, except for $\mathrm{H}_{2} \mathrm{O}$ and $\mathrm{O}_{3}$, which were constrained to the measured values in the model. Although the $\mathrm{RO}_{\mathrm{x}}$ mixing ratios were overestimated during the major dust event, no clear relation to the presence of dust aerosol could be found.

The HCHO mixing ratio is significantly overestimated by the model, which could at least partly be explained by the neglect of dry deposition. The calculated $\mathrm{HCHO}$ mixing ratio is very sensitive to the input concentrations of isoprene and $\mathrm{CH}_{3} \mathrm{OOH}$, which are both subject to large measurement uncertainties. It has been shown that the airmass might not have reached steady state with respect to isoprene (and other locally emitted biogenic species), and that a neglect of isoprene in the model simulations provides the best agreement with the measured $\mathrm{HCHO}$ and $\mathrm{RO}_{\mathrm{x}}$ mixing ratios. Probably a combination of the neglect of dry deposition, an overestimation of the $\mathrm{CH}_{3} \mathrm{OOH}$ and isoprene mixing ratios and the fact that the airmass might not be in steady state with respect to isoprene causes the disagreement between observation and boxmodel calculations. However, we cannot finally exclude the possibility of an underestimation of the observed $\mathrm{HCHO}$ mixing ratios.

The observed $\mathrm{H}_{2} \mathrm{O}_{2}$ mixing ratios could only be reproduced with the box model when dry deposition was included. However, even after including dry deposition, the $\mathrm{H}_{2} \mathrm{O}_{2}$ mixing ratios were strongly overestimated during the Saharan dust event. A much better agreement between the observed and calculated $\mathrm{H}_{2} \mathrm{O}_{2}$ mixing ratios could be achieved by adding heterogeneous removal reactions of $\mathrm{HO}_{2}$ and $\mathrm{H}_{2} \mathrm{O}_{2}$. A relatively low $\mathrm{H}_{2} \mathrm{O}_{2}$ accommodation coefficient of $5 \times 10^{-4}$ was sufficient to reproduce the observed $\mathrm{H}_{2} \mathrm{O}_{2}$ mixing ratios during the dust event. Good agreement between the model and observations was also obtained by considering heterogeneous removal of $\mathrm{HO}_{2}$ with an accommodation coefficient of 0.2 . However, if we assume that $\mathrm{H}_{2} \mathrm{O}_{2}$ is formed during the heterogeneous reaction of $\mathrm{HO}_{2}$ on mineral dust aerosol, the additional $\mathrm{H}_{2} \mathrm{O}_{2}$ production had to be compensated with heterogeneous removal of $\mathrm{H}_{2} \mathrm{O}_{2}$ with a higher accommodation coefficient $\left(2 \times 10^{-3}\right)$ to obtain a good agreement between the modelled and observed values. Given that the measurements clearly indicate the uptake of $\mathrm{HO}_{2}$ and/or $\mathrm{H}_{2} \mathrm{O}_{2}$ on Saharan dust aerosol, laboratory studies of the uptake of $\mathrm{HO}_{2}$ and $\mathrm{H}_{2} \mathrm{O}_{2}$ on mineral dust aerosol are needed.

The low ozone mixing ratios observed during the Saharan dust event cannot be analysed with the boxmodel without making assumptions on the concentrations of $\mathrm{O}_{3}$ and other trace gases in the dust source area. Therefore, we calculated the net ozone production rate for dust-loaded and dust-poor airmasses. Due to the relatively low $\mathrm{RO}_{\mathrm{x}}$ and $\mathrm{NO}$ mixing ratios in the Saharan dust plume the NOP is significantly reduced compared to the dust-poor airmasses, which may explain the difference in $\mathrm{O}_{3}$ mixing ratios observed in those airmasses. However, heterogeneous removal of $\mathrm{O}_{3}$ on Saharan dust particles cannot be excluded. An average net ozone production rate of $0.14 \mathrm{ppb}_{\mathrm{v}} / \mathrm{hr}$ has been calculated within the dust plume when the observed $\mathrm{RO}_{\mathrm{x}}$ mixing ratios were used and $0.33 \mathrm{ppb}_{\mathrm{v}} / \mathrm{hr}$ when the calculated $\mathrm{RO}_{\mathrm{x}}$ mixing ratios were used. The daily average NOP ranged between 0.15 and $3.7 \mathrm{ppb}_{\mathrm{v}} / \mathrm{hr}$ in the dust-poor airmasses, while the overall average daytime NOP was $1.06 \mathrm{ppb}_{\mathrm{v}} / \mathrm{hr}$.

Acknowledgements. We would like to thank E. Cuevas and his team for their technical support at the Izaña observatory and Astrid Kerkweg for her help with the modelling. The MINATROC project was financially supported by the European Commission (DG XII). 
Edited by: W. T. Sturges

\section{References}

Ayers, G. P., Gillet, R. W., Granek, H., de Serves, C., and Cox, R. A.: Formaldehyde production in clean marine air, Geophys. Res. Lett., 24, 401-404, 1997.

Bauer, S. E., Balkanski, Y., Schulz, M., and Haughlustaine, D. A.: Global modeling of heterogeneous chemistry on mineral aerosol surfaces: Influence on tropospheric ozone chemistry and comparison to observations, J. Geophys. Res., 109, D02304, doi:10.1029/2003JD003868, 2004.

Bian, H. and Zender, C. S.: Mineral dust and global tropospheric chemistry: Relative roles of photolysis and heterogeneous uptake, J. Geophys. Res., 108, D21, 4672, doi:10.1029/2002JD003143, 2003.

Bonasoni, P., Cristofanelli, P., Calzolari, F., Bonafe, U., Evangelisti, F., Stohl, A., Zauli Sajani, S., van Dingenen, R., Colombo, T., and Balkanski, Y.: Aerosol-ozone correlations during dust transport episodes, Atmos. Chem. Phys., 4, 1201-1215, 2004,

SRef-ID: 1680-7324/acp/2004-4-1201.

Cantrell, C. A., Shetter, R. E., Gilpin, T. M., and Calvert, J. G.: Peroxy radicals measured during Mauna Loa Observatory Photochemistry Experiment 2: The data and first analyses, J. Geophys. Res., 101, 14643-14 652, 1996.

Carslaw, N., Plane, J. M. C., and Coe, H.: Observations of the nitrate radical in the free troposphere at Izaña de Tenerife, J. Geophys. Res., 102, 10613-10 622, 1997.

Clegg, S. M. and Abbatt, J. P. D.: Uptake of gas-phase $\mathrm{SO}_{2}$ and $\mathrm{H}_{2} \mathrm{O}_{2}$ by ice surfaces: dependence on partial pressure, temperature and surface acidity, J. Phys. Chem. A., 105, 6630-6636, 2001.

Cooper, P. L. and Abbatt, J. P. D.: Heterogeneous interactions of $\mathrm{OH}$ and $\mathrm{HO}_{2}$ radicals with surfaces characteristic of atmospheric particulate matter, J. Phys. Chem., 100, 2249-2254, 1996.

Crutzen, P. J. and Arnold, F.: Nitric-acid cloud formation in the cold Antarctic stratosphere - a major cause for the springtime ozone hole, Nature, 324, 651-655, 1986.

Dentener, F. J., Carmichael, G. R., Zhang, Y., Lelieveld, J., and Crutzen, P. J.: Role of mineral aerosol as a reactive surface in the global troposphere. J. Geophys. Res., 101, 22 869-22 889, 1996.

de Reus, M., Dentener, F., Thomas, A., Borrmann, S., Ström, J., and Lelieveld, J.: Airborne observations of dust aerosol over the North Atlantic Ocean during ACE-2: indications for heterogeneous ozone destruction. J. Geophys. Res., 105, 15 263-15 275, 2000.

Fischer, H., Niktas, C., Parchatka, U., Zenker, T., Harris, G. W., Matuska, P., Schmitt, R., Mihelcic, D., Muesgen, P., Paetz, H.W., Schultz, M., and Volz-Thomas, A.: Trace gas measurements during the Oxidizing Capacity of the Tropospheric Atmosphere campaign 1993 at Izana, J. Geophys. Res., 103, 13 505-13 518, 1998.

Fischer, H., Kormann, R., Klüpfel, T., Gurk, Ch., Königstedt, R., Parchatka, U., Mühle, J., Rhee, T. S., Brenninkmeijer, C. A. M., Bonasoni, P., and Stohl, A.: Ozone production and trace gas correlations during the June 2000 MINATROC intensive measurement campaign at Mt. Cimone, Atmos. Chem. Phys., 3, 725-738, 2003, SRef-ID: 1680-7324/acp/2003-3-725.
Fuchs, N. A. and Sutugin, A. G.: Highly Dispersed Aerosols, 105 pp., Butterworth-Heinemann, Woburn, Mass., 1970.

Gros, V., Williams, J., van Aardenne, J. A., Salisbury, G., Hofmann, R., Lawrence, M. G., von Kuhlmann, R., Lelieveld, J., Krol, M., Berresheim, H., Lobert, J. M., and Atlas, E.: Origin of anthropogenic hydrocarbons and halocarbons measured in the summertime European outflow (on Crete in 2001), Atmos. Chem. Phys., 3, 1223-1235, 2003, SRef-ID: 1680-7324/acp/2003-3-1223.

Hanisch, F. and Crowley, J. N.: Ozone decomposition on Saharan dust: an experimental investigation, Atmos. Chem. Phys., 3, 119-130, 2003,

\section{SRef-ID: 1680-7324/acp/2003-3-119.}

Hanke, M., Umann, B., Ueker, J., Arnold, F., and Bunz, H.: Atmospheric measurements of gas-phase $\mathrm{HNO}_{3}$ and $\mathrm{SO}_{2}$ using chemical ionization mass spectrometry during the MINATROC field campaign 2000 on Mont Cimone, Atmos. Chem. Phys., 3, 417436, 2003, SRef-ID: 1680-7324/acp/2003-3-417.

Hanson, D. R., Burkholder, J. B., Howard C. J., and Ravishankara, A. R.: Measurement of $\mathrm{OH}$ and $\mathrm{HO}_{2}$ radical uptake coefficients on water and sulphuric acid surfaces, J. Phys. Chem., 96, 49794985, 1992.

Heikes, B. G. and Thompson, A. M.: Effects of heterogeneous processes on $\mathrm{NO}_{3}, \mathrm{HONO}$ and $\mathrm{HNO}_{3}$ chemistry in the troposphere, J. Geophys. Res., 88, 10 883-10 895, 1983.

Heikes, B., Lee, M., Jacob, D., Talbot, R., Bradshaw, J., Singh, H., Blake, D., Anderson, B., Fuelberg, H., and Thompson, A. M.: Ozone, hydroperoxides, oxides of nitrogen, and hydrocarbon budgets in the marine boundary layer over the South Atlantic, J. Geophys. Res., 101, 24 221-24 234, 1996.

IPCC (Intergovernmental Panel on Climate Change): Climate change 1995, edited by: Houghton, J. T., Meira Filho, L. G., Callender, B. A., Harris, N., Kattenberg, A., and Maskell, A., Cambridge University Press, Cambridge, UK, 572 p., 1996.

Jacob, D. J.: Heterogeneous chemistry and tropospheric ozone, Atm. Environ., 34, 2131-2159, 2000.

Jaeglé, L. Jacob, D. J., Brune, W. H., Faloona, I., Tan, D., Heikes, B. G., Kondo, Y., Sachse, G. W., Anderson, B., Gregory, G. L., Singh, H. B., Pueschel, R., Ferry, G., Blake, D. R., and Shetter, R. E.: Photochemistry of Hox in the upper troposphere at northern latitudes, J. Geophys. Res., 105, 3877-3892, 2000.

Junkermann, W. and Stockwell, W. R.: On the budget of photooxidants in the marine boundary layer of the tropical South Atlantic, J. Geophys. Res., 104, 8039-8046, 1999.

Kormann, R., Fischer, H., de Reus, M., Lawrence, M., Bruhl, C., von Kuhlmann, R., Holzinger, R., Williams, J., Lelieveld, J., Warneke, C., de Gouw, J., Heland, J., Ziereis, H., and Schlager, H.: Formaldehyde over the eastern Mediterranean during MINOS: Comparison of airborne in-situ measurements with 3Dmodel results, Atmos. Chem. Phys., 3, 851-861, 2003,

SRef-ID: 1680-7324/acp/2003-3-851.

Lazrus, A. L., Kok, G. L., Lind, J. A., Gitlin, S. N., Heikes, B. G., and Shetter, R. E.: Automated fluorometric method for hydrogen-peroxide in air, Anal. Chem., 58, 594-597, 1986.

Lelieveld, J. and Crutzen, P. J.: Influences of cloud photochemical processes on tropospheric ozone, Nature, 343, 227-233, 1990.

Lelieveld, J., van Aardenne, J., Fischer, H., de Reus, M., Williams, J., and Winkler, P.: Increasing ozone over the Atlantic Ocean, doi:10.1126/science.1096777, Science, 2004. 
Lindinger, W., Hansel, A., and Jordan, A.: On-line monitoring of volatile organic compounds at pptv levels by means of ProtonTransfer-Reaction Mass Spectrometry (PTR-MS): Medical applications, food control and environmental research, Int. J. Mass Spectrom. Ion Processes, 173, 191-241, 1998.

Liu, S.C., Kley, D., McFarland, M., Mahlmann, J. D., and Levi, H.: On the origin of tropospheric ozone, J. Geophys. Res., 85, 7546-7552, 1980.

Madronich, S., and Flocke, S.: The role of solar radiation in atmospheric chemistry, in: Handbook of Environmental Chemistry, edited by: Boule, P., Springer-Verlag, Heidelberg, pp. 1-26, 1998.

Mozurkewich, M., McMurry, P. H., Gupta, A., and Calvert, J. G.: Mass accommodation coefficient for $\mathrm{HO}_{2}$ radicals on aqueous particles, J. Geophys. Res., 92, 4163-4170, 1987.

Novelli, P. C., Masarie, K. A., Lang, P. M., Hall, B. D., Myers, R. C., and Elkins, J. W.: Reanalyisis of tropospheric CO trends: Effects of the 1997-1998 wildfires, J. Geophys. Res., 108, D15, 4464, doi:10.1029/2002JD003031, 2003.

Olson, J. R., Crawford, J. H., Chen, G., Fried, A., Evans, M. J., Jordan, C. E., Sandholm, S. T., Davis, D. D., Anderson, B. E., Avery, M. A., Barrick, J. D., Blake, D. R., Brune, W. H., Eisele, F. L., Flocke, F., Harder, H., Jacob, D. J., Kondo, Y., Lefer, B. L., Martinez, M., Mauldin, R. L., Sachse, G. W., Shetter, R. E., Singh, H. B., Talbot, R. W., and Tan, D.: Testing fast photochemical theory during TRACE-P based on measurements of $\mathrm{OH}, \mathrm{HO}_{2}$ and $\mathrm{CH}_{2} \mathrm{O}$, J. Geophys. Res., 109, D15S10, doi:10.1029/2003JD004278, 2004.

O' Sullivan, D. W., Heikes, B. G., Lee, M., Chang, W., Gregory, G. L., Blake, D. R., and Sachse, G. W.: Distribution of hydrogen peroxide and methylhydroperoxide over the Pacific and South Atlantic Oceans, J. Geophys. Res., 104, 5635-5646, 1999.

Salisbury, G., Williams, J., Holzinger, R., Gros, V., Mihalopoulos, N., Vrekousis, M., Sarda-Esteve, R, Berresheim, H., von Kuhlmann, R., Lawrence, M., and Lelieveld, J.: Ground-bases PTR-MS measurements of reactive organic compounds during the MINOS campaign in Crete, July-August 2001, Atmos. Chem. Phys., 3, 925-940, 2003,

SRef-ID: 1680-7324/acp/2003-3-925.

Sander, R., Kerkweg, A., Jöckel, P., and Lelieveld, J.: Technical Note: The new comprehensive atmospheric chemistry module MECCA, Atmos. Chem. Phys. Discuss., 4, 7167-7180, 2004, SRef-ID: 1680-7375/acpd/2004-4-7167.

Sander, S. P., Finlayson-Pitts, B. J., Friedl, R. R., Golden, D. M., Huie, R. E., Kolb, C. E., Kurylo, M. J., Molina, M. J., Moortgat, G. K., Orkin, V. L., and Ravishankara, A. R.: Chemical Kinetics and photochemical data for use in atmospheric studies, Evaluation number 14, JPL Publications 02-25, Jet Propulsion Laboratory, Pasadena, CA, 2003.

Schultz, M.: Die Bedeutung von Stickoxiden für die Ozonbilanz in Reinluftgebieten, Untersuchung der Photochemie in Reinluft anhand von Spurengasmessungen auf Teneriffa, Ph.D. thesis, Bergischen Universität Wuppertal, Germany, 185 p., 1995.

Singh, H. B., Salas, L. J., Chatfield, R. B., Czech, E., Fried, A., Walega, J., Evans, M., Field, B. D., Jacob, D. J., Blake, D., Heikes, B., Talbot, R., Sachse, G., Crawford, J. H., Avery, M. A., Sandholm, S., and Fuelberg, H.: Analysis of the atmospheric distribution, sources, and sinks of oxygenated volatile organic chemicals based on measurements over the
Pacific during TRACE-P, J. Geophys. Res., 109, D15S07, doi:10.1029/2003JD003883, 2004.

Tang, Y., Carmichael, G. R., Kurata, G., Uno, I., Weber, R. J., Song, C. H., Guttikunda, S. K., Woo, J. H., Streets, D. G., Wei, C., Clarke, A. D., Huebert, B., and Anderson, T. L.: Impacts of dust on regional tropospheric chemistry during the ACE-Asia experiment: A model study with observations, J. Geophys. Res., 109, D19S21, doi:10.1029/2003JD003806, 2004.

Underwood, G. M., Li, P., Al-Abadleh, H., and Grassian, V. H.: A Knudsen cell study of the heterogeneous reactivity of nitric acid on oxide and mineral dust particles, J. Phys. Chem. A, 105, 6609-6620, 2001.

Usher, C. R., Michel, A. E., and Grassian, V. H., Reactions on mineral dust, Chem. Rev., 103, 4883-4939, 2003.

von Kuhlmann, R., Lawrence, M. G., Crutzen, P. J., and Rasch, P. J.: A model for studies of tropospheric ozone and non-methane hydrocarbons: Model description and ozone results, J. Geophys. Res., 108, D9, doi:10.1029/2002JD002893, 2003.

Wagner, V., von Glasow, R., Fischer, H., and Crutzen, P. J.: Are $\mathrm{CH}_{2} \mathrm{O}$ measurements in the marine boundary layer suitable for testing the current understanding of $\mathrm{CH}_{4}$ photooxidation?: A model study, J. Geophys. Res., 107, D3, doi:10.1029/2001JD000722, 2002.

Weinstein-Lloyd, J. B., Lee, J. H., Daum, P. H., Kleinman, L. I., Nunnermacker, L. J., Springston, S. R., and Newman, L.: Measurements of peroxides and related species during the 1995 summer intensive of the Southern Oxidants Study in Nashvill, Tennessee, J. Geophys. Res., 103, 22 361-22 373, 1998.

Weller, R., Schrems, O., Boddenberg, A., Gäb, S., and Gautrois, M.: Meridional distribution of hydroperoxides and formaldehyde in the marine boundary layer of the Atlantic $\left(48^{\circ} \mathrm{N}-35^{\circ} \mathrm{S}\right)$ measured during the Albatross campaign, J. Geophys. Res., 105, 14 401-14 412, 2000.

Williams, J., Pöschl, U., Crutzen, P. J., Hansel, A., Holzinger, R., Warneke, C., Lindinger, W., and Lelieveld, J.: An atmospheric chemistry interpretation of mass scans obtained from a proton transfer mass spectrometer flown over the tropical rainforest of Surinam, J. Atmos. Chem., 38, 133-166, 2001.

Worsnop, D. R., Zahniser, M. S., Kolb, C. E., Gardner, J. A., Watson, L. R., Van Doren, J. M., Jayne, J. T., and Davidovits, P.: Temperature dependence of mass accommodation of $\mathrm{SO}_{2}$ and $\mathrm{H}_{2} \mathrm{O}_{2}$ on aqueous surfaces, J. Phys. Chem., 93, 1159-1172, 1989.

Zaveri, R. A., Saylor, R. D., Peters, L. K., McNider, R., and Song, A.: A model investigation of summertime diurnal ozone behaviour in rural mountainous locations, Atmos. Enironm., 29, 1043-1065, 1995.

Zhang, Y., Sunwoo, Y., Kotamarthi, V., and Carmichael, G. R.: Photochemical oxidant processes in the presence of dust: an evaluation of the impact of dust on particulate nitrate and ozone formation, J. Appl. Meteorol., 33, 813-824, 1994.

Zhang, Y. and Carmichael, G. R.: The role of mineral aerosol in tropospheric chemistry in East Asia - a model study, J. Appl. Meteorol., 38, 353-366, 1999.

Zhou, X., Lee, Y. N., Newman, L., Chen, X., and Mopper, K.: Tropospheric formaldehyde concentrations at the Mauna Loa Observatory during the Mauna Loa Observatory Photochemistry Experiment 2, J. Geophys. Res., 101, 14 711-14 719, 1996. 